\title{
Regulatory strategies in environmental liability
}

\author{
Citation for published version (APA):
}

Faure, M. G. (2009). Regulatory strategies in environmental liability. In F. Cafaggi, \& H. Muir Watt (Eds.), The Regulatory Function of European Private Law (pp. 129-187). Edward Elgar Publishing. https://doi.org/10.4337/9781848447264.00014

Document status and date:

Published: 01/01/2009

DOI:

10.4337/9781848447264.00014

Document Version:

Publisher's PDF, also known as Version of record

Document license:

Taverne

\section{Please check the document version of this publication:}

- A submitted manuscript is the version of the article upon submission and before peer-review. There can be important differences between the submitted version and the official published version of record.

People interested in the research are advised to contact the author for the final version of the publication, or visit the DOI to the publisher's website.

- The final author version and the galley proof are versions of the publication after peer review.

- The final published version features the final layout of the paper including the volume, issue and page numbers.

Link to publication

\footnotetext{
General rights rights.

- You may freely distribute the URL identifying the publication in the public portal. please follow below link for the End User Agreement:

www.umlib.nl/taverne-license

Take down policy

If you believe that this document breaches copyright please contact us at:

repository@maastrichtuniversity.nl

providing details and we will investigate your claim.
}

Copyright and moral rights for the publications made accessible in the public portal are retained by the authors and/or other copyright owners and it is a condition of accessing publications that users recognise and abide by the legal requirements associated with these

- Users may download and print one copy of any publication from the public portal for the purpose of private study or research.

- You may not further distribute the material or use it for any profit-making activity or commercial gain

If the publication is distributed under the terms of Article $25 \mathrm{fa}$ of the Dutch Copyright Act, indicated by the "Taverne" license above, 


\title{
M-EPLI
}

MAASTRICHT EUROPEAN PRIVATE LAW INSTITUTE

WORKING PAPER No. 2011/22

\section{REGULATORY STRATEGIES IN ENVIRONMENTAL LIABILITY}

Michael Faure

\section{Mast Maastricht University}

\author{
FACULTY OF LAW \\ MAASTRICHT UNIVERSITY
}

JUNE 2011

The paper can be downloaded without charge from the Social Science Research Network at http://www.ssrn.com 


\title{
REGULATORY STRATEGIES IN ENVIRONMENTAL LIABILITY
}

\author{
Michael Faure \\ michael.faure@maastrichtuniversity.nl
}

\begin{abstract}
This paper analyses the possibilities of private law in remedying environmental damage. The preventive role of tort law is discussed as well as its relationship to regulation. Attention is also paid to the necessity to combine liability and regulation and to the environmental liability directive. Conditions for the insurability of environmental harm are discussed and attention is paid to alternative compensation mechanisms for environmental harm such as environmental damage insurance and compensation funds. Also, arguments in favour of harmonization of environmental liability are critically discussed.
\end{abstract}

Keywords: tort law, liability, strict liability, negligence, environmental liability, European private law, regulation, insolvency, liability insurance, risk differentiation, causal uncertainty, retrospective liability, environmental damage insurance, harmonization

Published in: THE REGULATORY FUNCTION OF EIROPEAN PRIVATE LAW, pp. 129-187, Cafaggi, F., Watt, H. Muir, eds., Cheltenham, Edward Elgar, 2009 


\section{The Regulatory Function of European Private Law}

Edited by

Fabrizio Cafaggi

European University Institute, Italy

and

Horatia Muir Watt

Université de Paris 1 Panthéon-Sorbonne, France

\section{Edward Elgar}

Cheltenham, UK • Northampton, MA, USA 
(c) Fabrizio Cafaggi and Horatia Muir Watt 2009

All rights reserved. No part of this publication may be reproduced, stored in a retrieval system or transmitted in any form or by any means, electronic, mechanical or photocopying, recording, or otherwise without the prior permission of the publisher.

Published by

Edward Elgar Publishing Limited

The Lypiatts

15 Lansdown Road

Cheltenham

Glos GL50 2JA

UK

Edward Elgar Publishing, Inc.

William Pratt House

9 Dewey Court

Northampton

Massachusetts 01060

USA

A catalogue record for this book

is available from the British Library

Library of Congress Control Number: 2008939740

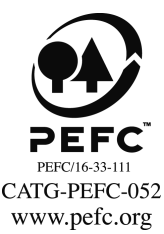

ISBN 9781847201997

Typeset by Cambrian Typesetters, Camberley, Surrey

Printed and bound in Great Britain by MPG Books Ltd, Bodmin, Cornwall 


\section{Regulatory strategies in environmental liability}

\section{Michael G. Faure}

\section{INTRODUCTION}

The question what the particular task of private law is in remedying environmental damage has in recent years been discussed extensively in the literature. Economists, starting from the idea that, in a situation where transaction costs are prohibitive and hence private bargaining cannot provide efficient solutions, stress that private law may be one of the instruments to be used to address the market failure caused by environmental damage. Indeed, the traditional way in which economists would approach environmental issues is usually by stressing the fact that there is a reason for law to intervene given the market failure constituted by the externality resulting from the environmental damage. Law in general should then, stated very basically, have as a goal that the marginal social costs caused by the externality should be taken into account by the decision maker. The environmental damage should, in other words, be internalized.

Lawyers have, with different wordings of course, also pointed at various benefits of private law in remedying environmental damage. Although they tend to attach less belief than economists to the preventive function of liability rules, legal doctrine also has often stressed that it is important to impose the costs due to environmental damage upon polluters since this may provide them incentives to abate environmental pollution. Often legal principles (even incorporated into international conventions) have been used to justify this idea. Well known in this respect is of course the 'polluter pays' principle.

The goal of this chapter is to sketch how, following this legal and economic literature, private law can play a role in the governance of environmental risks. This is a very broad and seemingly abstract question and it would take several books to answer it. Given the necessary limits of this chapter, that is of course not possible. Therefore in this chapter to some extent the main results of the legal and economic literature that has addressed the role of private law in remedying environmental damage will be presented. These issues have, moreover, not been dealt with in the abstract (for example just by analysing them 
within the context of economic models). Quite often the effectiveness or efficiency of specific environmental liability regimes has been critically reviewed. Thus in this chapter the way in which private law tackles environmental problems will be looked at both from the economic literature, and also by addressing tendencies in some member states and of course within the European Union. Since Europe finally adopted in 2004 a European Directive on remedying environmental damage some attention will have to be given to that document as well.

By addressing the role of private law in remedying environmental damage I will limit myself necessarily to one instrument of private law, being environmental liability, in other words tort law. Of course other instruments of private law could be thought of as well. Property rules and legal instruments related to property law (like nuisance law) are in many legal systems used as remedies in the fight against environmental pollution as well. And in some cases contract solutions may provide a remedy as well. However, the main instrument of private law in legal practice is undoubtedly liability law. Therefore I will mainly focus on that instrument.

The approach that will be taken in this chapter is by using on the one hand the knowledge acquired from the rich literature addressing environmental liability from a so-called law and economics perspective, but on the other hand by also looking at some developments within Europe. Thus the chapter will to some extent be positive, in the sense that it will mainly describe some evolutions in the way some member states (and Europe) have been using private law in remedying environmental damage. At the same time the economic literature especially will be used to come to some policy conclusions with respect to the way in which private law should probably be used in remedying environmental damage. As far as economics is used to address these policy issues the chapter is therefore unavoidably normative as well.

A great number of various topics within environmental liability could theoretically be addressed given the enormous richness of this literature as it has been developed during the past decades. However, since we have to select we will focus on those issues that are crucial in analysing what the role of environmental liability can be in preventing and compensating for environmental damage. Those two questions will therefore be the crucial ones. The question will indeed be addressed whether environmental liability is able (and to what extent) to prevent environmental damage and whether it can also provide compensation. At the same time the limits of environmental liability in providing both prevention and compensation will be addressed as well.

Especially within the context of a project interested in various regulatory approaches and tools, a focus on private law and more particularly liability is interesting since it has always been considered as a 'market solution'. Even in the context of the discussion of new so-called 'economic' environmental 
policy instruments, the importance of liability rules to guide the behaviour of potential polluters is often mentioned. However, many have of course rightly pointed at the fact that in comparison the role of private law in preventing environmental harm will often be limited. Most of the preventive behaviour will probably be the result of regulatory tools. Still this merits some attention to the question whether liability can play an additional role in backing up a regulation.

Within the context of a project on strategies and governance in European private law the question also needs to be briefly addressed whether there is any justification for a 'Europeanization' of the way in which private law deals with environmental liability. Again this is a question which has been addressed in economic literature. From a legal perspective the question has apparently been answered in the positive, given the fact that Europe has issued an important directive dealing with environmental damage. Nevertheless it still is interesting, also with a view to jurisdictions other than Europe, to address the question what the precise functions of harmonization in this area could be.

Of course, as mentioned already, this chapter merely aims at providing a 'tour d'horizon' of the issues at stake in environmental liability. It therefore necessarily builds on earlier research and is rather meant to give an overview of where legal and economic research in this domain stands today, as well as evolutions at the policy level.

On the basis of these starting points, after this introduction (section 1) the following issues will be addressed: first the question will be asked whether and how tort law can assist in preventing environmental damage (section 2). Necessarily then the question will be addressed why in practice it is mainly regulation that exercises this preventive function (section 3 ) and whether there still can be a complementary role for liability law in addition to regulation (section 4). Next the issue of compensation has to be addressed whereby unavoidably the compensatory role of tort law and its limits has to be addressed briefly (section 5). Immediately it will be shown that, without a backup by a financial security such as liability insurance, tort law provides little by way of a guarantee of compensation. However, liability insurance also has its limits in providing compensation especially in the area of diffuse environmental damage (section 6). Therefore many have addressed alternatives for liability insurance in providing compensation for environmental damage. An interesting alternative, since it again builds on a private initiative, is the tendency to use environmental damage insurance instead of liability insurance (section 7). Although all of these approaches fit into 'private law' the question of course also needs to be addressed whether there is any role for government, even when sticking to the private law solution. Can government be of any help, for example in providing facilitative strategies to improve the functioning of the liability system instead of immediately turning to regulatory solutions 
(section 8)? Of course the question how harmonization is viewed both from a legal and from an economic perspective needs to be addressed as well (section 9). A final section (section 10) will address the challenging question whether there is indeed a role and future for private law in protecting the environment. Since this is a broad and ambitious agenda it has once more to be stressed that many of these topics can be touched upon briefly in this general overview. For in-depth analysis of the specific issues the reader will be referred to the literature mentioned in the references.

\section{PREVENTIVE ROLE OF TORT LAW}

One of the regulatory functions of private law is, at least from an economic perspective, within the context of environmental harm, to provide incentives to risk creators aimed at prevention. The way liability rules aim at prevention can moreover be considered as a market oriented approach or, if one wants, as the use of soft law instead of hard law. Indeed, the way tort law functions in providing these incentives is that it fixes a price for a specific violation of norms (negligence) or for reaching a certain consequence (strict liability), but it generally leaves it up to the parties to find the optimal mode to prevent environmental harm. We will have a quick look at how this regulatory function of environmental liability is seen from an economic perspective (2.1), then the functioning of the two major liability rules, negligence and strict liability, will be addressed (2.2) and a brief word will be spent on actual policy in the European Union in this domain (2.3).

\subsection{Economic Principles of Accident Law}

The economic analysis of law in general and of accident law more specifically starts from the belief that a legal rule and more particularly a finding of liability will give incentives to potential parties in an accident setting for careful behaviour. ${ }^{1}$ Thus, economists tend to stress the deterrent function of tort law. Lawyers on the other hand sometimes mention this deterrent function as well, but tend to attach more value to the compensation goal of accident law. This 'victim protection' argument is discussed in the law and economics literature as well. ${ }^{2}$ In that respect it is, however, often stressed that the best form of

For excellent overviews of the role of liability and insurability as 'engineering instruments' see Endres and Staiger 1996, pp. 79-93; Wagner 1999, pp. 1441-1480; Monti 2001, pp. 51-79 and Gimpel-Hinteregger 1994, pp. 19-58.

2 Schwartz showed that rules of tort law may serve both the aims of deterrence and corrective justice (Schwartz 1997, pp. 1801-1834). 
victim protection is to avoid victimization in the first place. Of course, no one will argue that prevention of accidents is not a way of victim protection as well. This difference in accent between both approaches is also characterized as an ex ante versus an ex post vision. Whereas lawyers tend to be more interested in the accident problem ex post, where there is a victim who needs to be compensated, economists look at the accident problem in an ex ante perspective by asking the question how an ex post finding of liability will influence ex ante the incentives for care-taking of potential parties in an accident setting.

Of course, the differences in approach between lawyers and economists are not really that black and white. There are lawyers who stress the deterrent function of tort law as well ${ }^{3}$ and some economists pay attention to compensation issues by stressing that accident law should also aim at an equitable loss spreading. ${ }^{4}$ Moreover, lawyers also argue that tort law should lead to duties of care, which aim at prevention.

From an economic perspective the main goal of liability rules is the minimization of what was called by Guido Calabresi, the primary accident costs: ${ }^{5}$ the costs of accident avoidance and the expected damage. Indeed, from a social point of view accidents do not only cause costs from the moment an accident occurs and harm is suffered; potential parties in an accident setting, both injurers and victims make investments in care to avoid the occurrence of an accident. Sometimes costs of care-taking are very clear and visible. We can refer for instance to the investments made by firms to reduce environmental pollution by investing in water-cleaning equipment or the investment to install safety controls to avoid product defects. But also the mere fact that in a traffic accident case both injurers and victims are limited in their freedom of movement, for instance because they have to drive or work carefully, is considered as a cost by economists. A difference is further made between so-called unilateral accidents in which only the care taken by one of the parties (the injurer) can influence the accident risk on the one hand and bilateral accidents in which the behaviour of both parties can influence the accident risk on the other hand. ${ }^{6}$ In a bilateral accident situation the goal of accident law should therefore be to give incentives to minimize the total costs of care-taking by the potential injurer and the potential victim and the expected damage that will occur in case of an accident.

Economists use classic cost/benefit analysis to determine what the level of care is that will lead to such minimization of the social costs of accidents. Not surprisingly, this can be found where the marginal costs of care-taking equal

$3 \quad$ See Koziol 1997, pp. 8-13.

4 See Veljanovski 1981, pp. 125-150.

5 See Calabresi 1961, pp. 499-553 and Calabresi 1970.

6 This distinction has been made by Shavell 1987, p. 7. 
the marginal benefits in accident reduction. ${ }^{7}$ Indeed, since care-taking has its price as well, a legal rule should not give incentives to avoid every possible accident that could occur, but only accidents that could be avoided by investments in care, of which the marginal costs are lower than or equal to the marginal benefits in accident reduction. It might well be that extremely high care could well additionally contribute to a reduction of the accident risk but the marginal costs of care-taking in that case might well be much higher than the additional benefit in accident reduction. Investments in care would in that case be inefficient and scarce resources would be spoiled. ${ }^{8}$ These levels of care where marginal costs of care-taking equal marginal benefits in accident reduction are referred to in the literature as optimal or efficient care levels. ${ }^{9}$

\subsection{Strict Liability versus Negligence}

After having defined the regulatory function of liability rules, being that from an economic perspective liability rules should provide incentives to risk creators to take optimal care, the next question (which has been extensively addressed in the literature) is which liability rule may provide these appropriate incentives and can, in other words, be considered as fitting in a regulatory strategy optimally to prevent environmental damage. The two legal rules distinguished in this respect are on the one hand the classic fault or negligence rule, such as for example the one incorporated in Article 1382 of the the French Civil Code and on the other hand the strict liability rule. The basic difference is that under a fault or negligence regime the risk creator is only due to compensate the victim when his behaviour falls short of a certain level of due care, to be determined by the court. Strict liability on the other hand lays a duty upon the injurer to compensate the victim irrespective of his behaviour. A strict liability rule only requires that there is a causal relationship between the activity of the injurer and the damage of the victim.

Economic literature holds that if a negligence rule is adopted, the injurer will take optimal care, provided the due care required in the legal system is equal to the optimal care as defined in the model..$^{10}$ This can be easily understood. If the judicial system sets the due care standard correctly, the injurer can avoid liability by taking due care. Thus he will have to take care to avoid the accident, but if he does so he can avoid paying the expected damage. Since the

7 Ibid.

8 This finding only holds in a risk neutral setting. In a case of risk aversion, higher investments in care might well be efficient since a reduction of accident risk will in that case also remove the disutility of risk from a risk averse person.

$9 \quad$ See Landes and Posner 1981, p. 870 and Polinsky 1983.

10 Shavell 1987, p. 8 and Calabresi 1975, p. 658. 
optimal care standard was defined as exactly that level of care where the marginal costs of care equal the marginal benefits in accident reduction, taking less than the due care standard will not be worthwhile for the individual injurer since it will increase his total expected costs. Thus a negligence rule will lead to an efficient outcome as long as the legal system defines the due care as equal to the optimal care of the model.

Also a strict liability rule will lead to the optimum in a case where only one party can influence the accident risk. The reason is quite simple. A strict liability rule basically states that the injurer has to compensate in any case no matter what care he took. It is sometimes argued that this will lead the injurer to take excessive precautions or to take no care at all since he is liable anyway. Neither of these statements seems true. By making the injurer strictly liable, the social decision is in fact shifted to the injurer. In a unilateral accident case it simply means that he has to bear all the social costs of accidents, namely his own costs of care-taking and the expected damage. ${ }^{11}$ Therefore, he will take exactly the same decision, namely to minimize his total expected accident costs. We discussed in the model that this could be reached at the optimal care level. Therefore, the injurer will take optimal care since this is the way to minimize his total expected costs. Spending more on care would increase his costs of care-taking inefficiently and spending less on care would increase the expected damage inefficiently.

This leads to the conclusion that in this particular setting where we only considered the influence of the injurer's care on the accidents, both negligence and strict liability will provide incentives to take optimal care. Of course important nuances to this difference can be added. For instance the administrative costs of applying both rules differ. The strict liability rule seems to have the disadvantage that a legal case will follow with every accident since the injurer is always bound to compensate. Court costs can therefore be expected to be high. On the other hand, the negligence rule seems to have high information costs for the judge since he will have to determine in a particular case what the marginal costs and marginal benefits of care-taking were. ${ }^{12}$

The analysis of course can be much more refined, for instance if one goes into the bilateral accident situation. In that case, a contributory or comparative negligence defence has to be added to a strict liability rule to give victims an incentive as well to take optimal care. In other words, since victims would be fully compensated under strict liability, some defence should be added if the victim can equally influence the accident risk. Otherwise the victim would lack the incentives for prevention.

\footnotetext{
11 Polinsky 1983, p. 39; Shavell 1987, p. 11 and p. 8.

12 Brown 1973 p. 343; Calabresi 1975, p. 666, footnote 22 and Shavell 1987, p. 9.
} 
The advantage of the negligence rule in that case is that the victim will anyway assume that he has to bear the loss, so he will always have an incentive for taking optimal care. The simple reason is that a fully informed victim (which is obviously a strong assumption) will be aware of the fact that the injurer will take due care to avoid liability. Hence the victim is left with his loss and will automatically have incentives for prevention, even if no defences are added. A further refinement can be found when attention is given to factors other than care that can influence the accident risk. In the literature, attention, has especially been paid in that respect to the influence of the activity level. ${ }^{13}$

How does this test apply to the issue concerned in this chapter, being environmental liability? Environmental pollution can in most cases certainly be considered a unilateral accident, that is to say an accident whereby only the injurer can influence the accident risk. In this case we noted that the economic model predicts that the advantage of the strict liability rule is that it will give the injurer an incentive both to adopt an optimal activity level and to take efficient care. Since the victim cannot influence the accident risk, strict liability seems to be the best solution to give the potential polluter optimal incentives for accident reduction in those cases. ${ }^{14}$

There may, however, obviously be cases where other parties than the polluter could influence the risk of environmental degradation. These are not always the victims in the traditional sense. One can imagine cases where, for example, public or private actors would be responsible for managing a natural resource area. It might be desirable in those cases that liability also aims at giving them appropriate incentives to take those preventive measures. In that case environmental pollution would constitute a bilateral risk on the condition that one considers that third party a victim. ${ }^{15}$ However, since, in the example given, the influence of the polluter is probably still far more important than the influence of the other parties, the outcome does not change: a strict liability rule still is warranted to give the party who has most influence on the accident risk (the polluter) the incentive to take preventive measures. It is, however, important to remember that in bilateral cases a defence should always be added to victims as well. Moreover, if parties other than the polluter can also influence the accident risk, they might be held liable as well for the amount in which they contributed to the loss. That is, however, not an argument against the strict liability of the polluter.

\footnotetext{
13 See Adams 1989; Diamond 1974, pp. 107-164; Shavell 1980, pp. 1-25.

14 See for an application to nuclear liability; Faure 1995a, pp. 21-43.

15 Although it is then probably more a case where more parties can influence the accident risk (and should therefore be given appropriate incentives) since the actors in the example given cannot be considered traditional victims who suffer the loss personally (see also Niezen, Raaijmakers and Tervoort 2000, p. 171).
} 
So, if we apply the criteria of Shavell determining the choice between negligence and strict liability to the environmental case, there seem to be strong arguments in favour of an introduction of strict liability. In many cases environmental pollution will be truly unilateral in the sense that only the injurer's activity can influence the accident risk, which constitutes a strong case for strict liability. ${ }^{16}$

There is another important aspect of the difference between negligence and strict liability which should be mentioned. This concerns the fact that the application of negligence requires high information costs from the judge, who will have to set the due care standard. The information necessary to weigh costs and benefits and to fix the optimal care may not be readily available to the judge. Strict liability shifts all costs to the injurer, who will then have to define the optimal care level. If one therefore assumes that, as may be the case with environmental harm, the information on optimal precaution is more easily available to industry than to the judges, this constitutes an argument for strict liability. Note that obviously in some cases there may be an information advantage with the regulator. This is, as we will discuss below, an argument in favour of regulation, but not necessarily against strict liability. This information advantage may therefore constitute an additional argument in favour of strict liability for environmental harm.

One should, however, remember that this finding only holds in all the models, such as the one which has been developed by Shavell, which start from an assumption of risk neutrality. If risk aversion is introduced and the potential injurer is risk averse, Endres and Schwarze correctly argue that strict liability is only efficient if in some way risk can be removed from the risk averse injurer, for example through insurance. ${ }^{17}$ Moreover, we assume that the judge has accurate information on the amount of the damage. If courts err in assessing damages, strict liability will lead to underdeterrence. ${ }^{18}$

\subsection{Environmental Liability in European Private Law}

Of course a discussion of the regulatory function of liability rules within the context of a project on European private law should also pay some attention to

16 In some cases it will be the victim's activity that caused the harm, e.g. if the victim knowingly came to the nuisance. This may then lead to a denial of a claim for compensation. See in that respect the discussion on the coming to the nuisance doctrine, by Wittman 1980, pp. 557-568.

17 See Endres and Schwarze 1991, pp. 1-25.

18 If, in other words, courts can more easily observe the socially desirable level of precaution than the exact amount of external harm, a negligence rule should be favoured. This point has been made by Cooter 1984, pp. 1343-1523. 
recent developments in this respect at the policy level. The question of course more particularly arises as to what extent the preference for strict liability (at least in unilateral accident cases) can also be found back in legal practice. First of all it can be held that the move towards strict liability for environmental damage can be discovered in many legal systems in Europe. This is more particularly the case when it concerns liability for soil pollution. ${ }^{19}$ Indeed, one can point at developments in legislation and case law in many countries which indicate a general trend towards strict liability. Strict liability rules could already be found in many international conventions, for example in the civil liability convention of 29 November 1969 with respect to oil pollution damage $^{20}$ and also in the nuclear liability conventions (of Paris and Brussels), which equally impose a strict liability on the licensee of a nuclear power plant. Strict liability has also been introduced in the legislation of many countries. For instance section 7 of the 1995 Environmental Act in the UK imposes strict liability for soil pollution. ${ }^{21}$ Also chapter 32 of the 1998 Swedish Environmental Code provides for a strict joint and several liability regime and a duty to compensate for those whose activity would cause bodily injury, material damage and pecuniary losses. Chapter 10 of the same environmental code equally imposes a strict liability rule for soil contamination. Also the 1990 German Environmental Liability Act introduced a strict statutory liability. $^{22}$ In other countries the move towards strict liability did not result from formal changes in legislation, but from developments in case law. This is for instance the case in France where a broad interpretation of Article 1384, first line of Article 1384 of the Civil Code led effectively to a strict liability for example for polluted soils. ${ }^{23}$

19 For an overview, see Faure and Grimeaud 2003, pp. 68-122.

20 Faure, M. and Wang, H. (2006), 'Economic Analysis of Compensation for Oil Pollution Damage', Maritime Law and Commerce, 179-217.

21 For more details on the UK soil pollution regime, see McIntyre 1996, pp. 67-74. For an overview of environmental law in the UK, see Jones 1999. For an overview of the liability system for environmental damage in the UK, see also the 1996 McKenna Report, Study of Civil Liability Systems for Remedying Environmental Damage (Report for the European Commission, McKenna \& Co (now Cameron McKenna), Mistre House, 160 Aldersgate Street, London EC1A 4DD, UK) and the 2001 Clarke Report for the European Commission, Update Comparative Legal Study (update on the Mckenna Report): posted at: http://europa.eu.int/comm/environment/ liability/legalstudy.htm.

22 For an overview of environmental law in Germany, see Pape and Schillhorn 1999. See also the 1996 McKenna Report, above n. 21 and the 2001 Clarke Report for the European Commission, above n. 21. See also Hager 1993, pp. 41-44.

23 For a critical discussion of French tort law from an economic perspective, see Faure 2001a, pp. 169-181. 
This European-wide tendency towards strict liability now also seems to have reached the European Union with its Directive 2004/35/CE of 21 April 2004. ${ }^{24}$ Of course this is not the place to discuss the contents of the directive in any detail. It only seems interesting to verify to what extent the approach in the directive follows the lessons from economic analysis enabling environmental liability to exercise its regulatory function.

\section{REGULATION}

\subsection{Environmental Liability versus Regulation}

It is not difficult to argue that although environmental liability undoubtedly has an important task as a regulatory instrument to prevent environmental damage, it also has serious inherent limitations. Given these limitations some scholars therefore qualify the public law approach as 'the preferred approach' to prevent environmental damage. ${ }^{25}$ However, it would intellectually of course not be correct to qualify the fact that liability law cannot be applied to many cases of environmental damage as a shortcoming or limitation of tort law. The limitation of this instrument is that it of course can only be used when there is an identifiable victim and injurer and when a causal relationship can be established between an activity of the risk creator and the damage of the victim. If the injurer cannot be identified or the cause of the environmental damage cannot be established, liability law can indeed not be applied to this particular type of damage. However, this can hardly be considered as a 'shortcoming' of liability law; it simply means that the conditions for the application of liability law are not fulfilled. However, this does justify the conclusion that, if one wants to attain prevention of environmental harm, instruments other than liability law will have to be used.

Law and economics has paid a great deal of attention to the question whether safety in society can best be attained through liability rules or through regulation. An important contribution in this respect comes from Steven Shavell who examined the choice between liability rules and regulation in a thorough way. ${ }^{26}$ Both liability rules and regulation can be used to reach the same goal, being an optimal prevention of environmental harm. However, the way in which both instruments are used is totally different. If tort law is used, the risk creator remains free to choose the way in which environmental

\footnotetext{
24 Official Journal L143/56 of 30 April 2004.

25 See Bergkamp 2001, p. 208.

26 Shavell 1984a, pp. 357-374; Shavell 1984b, pp. 271-280 and Shavell 1987,
} pp. 277-290. 
damage can be prevented. Tort law assumes that the preventive function of liability rules will give incentives to the potential risk creator to introduce optimal preventive mechanisms. This is the case either because this is the optimal way for the potential risk creator to prevent the damage (under strict liability) or because it is a way to prevent having to pay compensation to the victim (under a negligence rule). Under regulation the government will ex ante impose the use of a particular preventive mechanism. Non-compliance with this preventive mechanism will also be enforced and can lead to the imposition of administrative or criminal sanctions. Regulation is thus considered as an $e x$ ante system aiming at prevention, whereas liability rules mainly intervene ex post after the damage has occurred. The criteria advanced by Steven Shavell that influenced safety regulation and liability are to be found in 3.2, 3.3 and 3.4.

\subsection{Information Asymmetries}

Information deficiencies have often been advanced as a cause of market failure and as the justification for government intervention through regulation. ${ }^{27}$ Also, for the proper operation of a liability system, information on for example the existing legal rules, the accident risk and efficient measures to prevent accidents, is a precondition for an efficient deterrence. According to Shavell, the parties in an accident setting generally have much better information on the accident risk than that possessed by the regulatory body. ${ }^{28}$ The parties themselves have, in principle, the best information on the costs and benefits of the activity that they undertake and of the optimal way to prevent accidents. This 'assumption of information' will, however, be reversed if it becomes clear that some risks are not readily appreciated by the parties in an accident setting. This may be a problem more particularly if costs are external. These cannot always be easily assessed by the parties involved.

\subsection{Insolvency}

If the potential damages can be so high that they will exceed the wealth of the individual injurer, liability rules will not provide optimal incentives. The reason is that the costs of care are directly related to the magnitude of the expected damages. If the expected damages are much greater than the individual wealth of the injurer, the injurer will only consider the accident as

27 See the basic article by Stigler 1961, p. 213 and see Schwartz and Wilde 1979, pp. 630-682 and Mackay 1982.

28 Shavell 1984a, p. 359. 
having a magnitude equal to his wealth. He will take, therefore, only the care necessary to avoid an accident equal to his wealth, which can be lower than the care required to avoid the total accident risk. ${ }^{29}$ This is a simple application of the principle that the deterrent effect of tort liability works only if the injurer has assets to pay for the damages he causes. If an injurer is protected against such liability, the problem of underdeterrence arises. ${ }^{30}$

Safety regulation can overcome this problem of underdeterrence caused by insolvency. ${ }^{31}$ In that case, the efficient care will be determined ex ante by regulation and will be affected by enforcement instruments which induce the potential injurer to comply with the regulatory standard, irrespective of his wealth.

Therefore, a problem might still arise if the regulation were also enforced by means of monetary sanctions. Again, if these were to exceed the injurer's wealth, the insolvency problem would remain. Hence, if a safety regulation is introduced because of a potential insolvency problem, the regulation itself should be enforced by non-monetary sanctions. ${ }^{32}$

\subsection{Underdeterrence of Tort Law}

Some activities can cause considerable damage, but even so a law suit to recover these damages may never be brought. If this were the case, there would of course be no deterrent effect of liability rules. Therefore, the absence of a liability suit would again be an argument to enforce the duty of efficient care by means of safety regulations rather than through liability rules. ${ }^{33}$ There can be a number of reasons why a law suit is not brought, even though considerable damage has been caused.

Sometimes an injurer can escape liability because the harm is thinly spread among a number of victims. As a consequence, the damage incurred by every individual victim is so small that there is no incentive to bring a suit. In particular, this problem will arise if the damage is not caused to an individual but to common property, such as the surface waters in which each member of the population has a minor interest. In addition, a long time might have elapsed

29 Ibid., p. 360.

30 Shavell 1986, pp. 43-58. Above we mentioned that insolvency causes a problem especially under a strict liability rule, but less so under negligence. See Section 5.2 at pp. $152-153$.

31 If insurance were to come into the picture it could overcome the problems of underdeterrence, provided that the moral hazard problem, caused by insurance, could be cured.

32 Shavell 1985a, pp. 1232-1262.

33 Shavell 1984a, p. 363. 
before the damage becomes apparent; in this case much of the necessary evidence may be either lost or not obtained. Another problem is that if the damage only manifests itself years after the activity, the injurer might have gone out of business.

A related problem is that it is often hard to prove that a causal link exists between an activity and a type of damage. ${ }^{34}$ The burden of proof of a causal relationship becomes more difficult with the increasing passage of time since the damaging incident took place. Often a victim will not recognize that the harm had been caused by a tort, but might think that his or her particular ailment, for example cancer, had a 'natural cause', associated with general ill health. For all these reasons, a liability suit might not be brought and hence safety regulation is necessary to ensure that the potential polluter takes efficient care. ${ }^{35}$

\subsection{Empirical Evidence}

For these reasons it is clear that some form of government regulation of environmental pollution is necessary. To reformulate: this shows that liability rules alone cannot suffice to prevent environmental harm, but there might be other, publicly imposed, instruments than the command and control type regulation which can be used to reach this goal. Taxes are obviously such an alternative. But these also are publicly imposed and can hence be considered as 'regulation'.

Although it is difficult to examine whether environmental regulation is generally also effective in reducing environmental harm, some studies have attempted to examine the effectiveness of safety regulation in controlling environmental harm. These studies do not address the specific quality of every environmental law, but examine whether regulation has generally been more important in reducing environmental harm than liability rules. Dewees demonstrated that in North America the quality of the environment has improved substantially as a result of regulatory efforts, not so much in response to legal action in tort. ${ }^{36}$

This empirical evidence of the success of regulation, compared to tort law, has been stressed in the book by Dewees, Duff and Trebilcock. ${ }^{37}$ They hold that the large regulatory effort to improve the environment has met with

\footnotetext{
$34 \quad$ See Landes and Posner 1984, p. 417 and Kunreuther and Freeman 2001, pp. 304-305.

35 For alternatives to liability suits, see Bocken 1987, pp. 83-87 and Bocken 1988, pp. 3-10.

36 Dewees 1992a, pp. 446-467 and Dewees 1992b, pp. 139-164.

37 Dewees, Duff and Trebilcock 1996.
} 
considerable success when measured by the reduction of emissions, but that it is more difficult to argue that the environmental regulations of the 1970s in the US equally had a considerable influence on the ambient environmental quality. Moreover, they also stress that while environmental regulation is a determining factor in pollutant emissions and ambient concentrations, other non-regulatory factors such as economic growth and even the weather also influence environmental quality. ${ }^{38}$

\section{NECESSITY TO COMBINE LIABILITY AND REGULATION}

We just stressed that according to Shavell's criteria there is a strong argument to control the environmental risk through ex ante regulation (or taxes). However, in individual cases there can still be damage to the environment. Then again, liability under tort comes into the picture and the question has been addressed in the literature how regulation influences the liability system and vice versa. The complementary relationship between tort law and regulation has been examined in detail by Rose-Ackerman, ${ }^{39}$ Faure and Ruegg, 40 Kolstad, Ulen and Johnson ${ }^{41}$ and recently by Arcuri ${ }^{42}$ and Burrows. ${ }^{43}$ RoseAckerman also compared US and European experiences in using regulation versus tort law in environmental policy. ${ }^{44}$

The first point which is often stressed is that the fact that there are many arguments in favour of ex ante regulation of the environment, does not mean that the tort system should not be used any longer for its deterring and compensating functions. One reason for still relying on the tort system is that the effectiveness of (environmental) regulation is dependent upon enforcement, which may be weak.

In addition, the influence of lobby groups on regulation, to which public choice theory has rightly pointed, can to some extent be overcome by combining safety regulation and liability rules. Moreover, safety regulation, for example emission standards in licences, can become outdated fast and often lacks flexibility, which equally merits a combination with tort rules. Hence, from the

\footnotetext{
$38 \quad$ Ibid., pp. 307-323.

39 Rose-Ackerman 1992a, pp. 223-243; Rose-Ackerman 1992b, pp. 118-131 and Rose-Ackerman 1996, pp. 13-39.

$40 \quad$ Faure and Ruegg 1994, pp. 39-60.

41 Kolstad, Ulen and Johnson 1990, pp. 888-901.

42 Arcuri 2001, pp. 39-40.

43 Burrows 1999, pp. 227-242.

44 Rose-Ackerman 1995b, pp. 312-332 and Rose-Ackerman 1995a.
} 
above it follows that although there is a strong case for safety regulation to control the environmental risk, tort rules will still play an important role as well. ${ }^{45}$ This obviously raises the question whether compliance with regulation will affect the liability issue. We will address this point in the next section.

These interdependencies between regulation and tort law raise a number of interesting questions that have been extensively addressed in the literature, but that will not be addressed in this chapter for the reason that these complementarities have been addressed by Anthony Ogus in Chapter 1 of this volume.

\section{COMPENSATION: THE LIMITS OF ENVIRONMENTAL LIABILITY}

As we mentioned when discussing the preventive versus the compensatory role of tort law, we noticed that economists tend to stress the deterrent function of tort law whereas lawyers tend to attach more value to the compensation goal of liability rules. This belief that tort law may have a compensatory function as well plays an important role in legal literature and has largely influenced the choice between strict liability and negligence, which was addressed above from an economic perspective.

\subsection{Negligence versus Strict Liability}

The reason that is often advanced in legal literature in favour of strict liability is that strict liability will help the victim to obtain compensation since he or she is released from the heavy burden of proving fault under the negligence rule. ${ }^{46}$ However, from a deterrence point of view victim compensation is not as such a goal of accident law. The duty of the injurer to compensate his victim is only an instrument to reach deterrence efficiency. Moreover, the victim compensation argument to introduce strict liability for environmental pollution is not that convincing in all cases. Indeed, many legal systems qualify every violation of a statutory or regulatory norm as a civil fault. Most industries are subjected to extensive safety regulation. Hence, in these systems the victim only has to prove the violation of one of these regulations to establish a fault. If, in addition, the victim can prove a causal relationship with the loss suffered, he or she will be able to claim compensation. In many accident cases

45 For a different analysis, leading to the same result that liability and regulation should be combined, see Schmitz 2000, pp. 371-382.

46 For an overview of all legal arguments in favour of strict environmental liability, see Jones 1997, pp. 11-27. 
this burden of proof will therefore not be as heavy as has been argued. It is, therefore, at least questionable whether a strict liability rule substantially improves the situation of the victim in comparison with an already existing broadly interpreted civil fault regime. It should also not be overlooked that under the general fault regime of tort law no limitations apply and the victim is entitled to full compensation. In many of the cases where strict liability was first introduced, more particularly in the international conventions concerning nuclear accidents and oil pollution, ${ }^{47}$ financial caps and other limitations on the victim's rights were introduced. The alleged compensating benefit of the strict liability in those cases is therefore doubtful.

Obviously arguments in favour of strict liability could also be based on distributional differences. These are more particularly distributional arguments which can often be found in the legal literature. Indeed, an important difference between strict liability and negligence is obviously that if the negligence rule works perfectly, the injurer will take the care that the legal system requires from him and will therefore not be held liable. A perfectly working negligence rule will therefore give appropriate incentives to the injurer, but not provide compensation to the victim. A strict liability rule is a rule which in principle guarantees compensation to the victim (if one disregards the insolvency issue, which we shall discuss below). It is precisely because of this distributional difference that many lawyers favour the strict liability rule. Remember, however, that from an economic perspective in bilateral cases strict liability is efficient only if a defence is added (contributory or comparative negligence) to give the victim incentives as well for effective prevention.

\subsection{Insolvency}

In sum, one should be careful with merely advocating strict liability because it would provide a better compensation to victims for the reasons (1) that these advantages are not always that obvious and (2) that the strict liability rule only guarantees compensation if we assume (unrealistically) a full solvency of the risk creator. Thus, tort law can never fulfil its compensatory goals if one were to stick to a negligence rule (the economic model showed that under negligence the injurer will in principle take due care and hence avoid having to pay compensation to the victim). Moreover, even if one were to shift (as we have seen in many countries) to strict liability, this shift only guarantees compensation to the victim if solvency guarantees are added as well. If these solvency

47 See with respect to nuclear accidents, Vanden Borre 2001; Faure and Skogh 1992, pp. 499-513; Deprimoz 1995, pp. 1-24; and see with respect to civil liability for marine oil pollution, Faure and Heine 1991, pp. 39-54; and see for recent evolutions, Brans 1994, pp. 61-67 and pp. 85-91. 
guarantees are not added, strict liability may even cause a problem of underdeterrence.

Under strict liability the injurer will consider the accident as one which is equal to his total wealth and will therefore only take the care necessary to avoid an accident with a magnitude equal to his total wealth. If that wealth is lower than the magnitude of an accident, he will take less than the optimal care and therefore a problem of underdeterrence arises under strict liability.

Insolvency is less of a problem under negligence since under that rule the injurer will still have an incentive to take the care required by the legal system as long as the costs of taking care are less than his individual wealth. Taking due care remains indeed a way for the injurer to avoid having to pay compensation to the victim. If there would thus be a potential accident setting whereby the magnitude of the loss may be higher than the injurer's wealth (which can often be the case in environmental liability) this constitutes an argument in favour of negligence rather than strict liability.

Indeed, strict liability is efficient only if an injurer is always held to pay fully for the consequences of the accident. If the injurer were insolvent or if the judge were to underestimate the amount of the damage underdeterrence would follow. ${ }^{48}$ Therefore, the negligence rule is better if the judge can adequately set the optimal level of care, even if there is uncertainty concerning the precise amount of the damage. If on the other hand, the judge can fix the amount of the damage with certainty (and the injurer is able to pay) but there would be error concerning the optimal care level, a strict liability rule would be the preferred rule. ${ }^{49}$

\subsection{Environmental Liability Directive}

From this perspective one could also formulate a serious criticism of Directive 2004/35 of 21 April 2004. The economic literature has indeed stressed, as we just mentioned, that strict liability can only exercise both its preventive and its compensatory function if the insolvency risk can be cured. It is therefore important to stress that if one assumes that insolvency may arise a remedy has to be found which can provide the injurer with adequate incentives. History has unfortunately shown that even companies with limited financial means may cause huge environmental damage and may thereafter be judgment proof. Moreover, the insolvency risk may even arise with larger companies since almost all (larger) companies are organized as legal entities and therefore

\footnotetext{
48 Cooter and Ulen 2000, pp. 316-318.

49 Cooter 1984, p. 1523.
} 
enjoy the benefits of the limited liability of the corporation. It is precisely because companies enjoy limited liability that some authors have argued that a serious underdeterrence may arise..$^{50}$

A problem in this respect is that Directive 2004/35 does not solve the insolvency problem. Article 14 merely states in respect of financial security:

\begin{abstract}
Member states shall take measures to encourage the development of financial security instruments and markets by the appropriate economic and financial operators, including financial mechanisms in case of insolvency, with the aim of enabling operators to use financial guarantees to cover their responsibilities under this directive.
\end{abstract}

This is a dangerous approach since the directive introduces strict liability for many activities. If this strict liability is not accompanied by a mandatory financial guarantee or insurance, underdeterrence may arise. Moreover, it seems clear that environmental liability, given the serious insolvency risk, cannot exercise its compensatory function unless a regulatory intervention has taken place to impose a duty to seek financial coverage. Hence the question has to be addressed whether insurance or other financial instruments are able to provide compensation.

\title{
6. COMPENSATION OF ENVIRONMENTAL HARM: LIABILITY INSURANCE
}

Of course many studies have addressed the issue of to what extent liability for environmental damage can be insured against. Attention in this literature has more particularly been given to the question under which conditions environmental damage can be considered insurable. ${ }^{51}$ It is of course not possible to repeat or even summarize the contents of this extensive body of literature within the scope of this chapter. However, we would like to focus on some of the main conclusions of this literature which basically show some of the problems that arise in providing insurance cover for environmental liability. A further insight into some of these problems may lead to a better understanding of why particularly the liability risk concerning environmental damage is often considered as 'hard to insure' by insurers. Studying these problems may make

\footnotetext{
$50 \quad$ See Hansmann and Kraakman 1991, p. 1879 and see Cortenraad 2000.

51 For a summary of this literature see Faure 2007, pp. 73-102 and Faure and Hartlief 2003, p. 260. For a summary see Kunreuther and Freeman 2001, pp. 305-306. See e.g. Abraham 1988, pp. 949-951; Katzman 1988, pp. 89-90; Cousy 1995, pp. 235-237 and Rogge 1997, pp. 3-6.
} 
it easier to understand why insurers increasingly seek different solutions from liability insurance, precisely because they consider some of these alternative arrangements better insurable (this will be addressed in section 7). What are the issues that particularly endanger the insurability of the liability risk for environmental damage?

\subsection{Predictability of the Risk}

Obviously for every insurance scheme, including environmental liability insurance, it is crucial that the insurer possesses accurate information on the likelihood that the event will occur (the probability) and on the possible magnitude of the damage once the accident does occur. These expectations on probability and magnitude of the loss are essential for the insurer to be able to calculate a fair premium. Added to this are the so-called loading costs (for, among other things, administrative expenses) and, depending on the market structure, a profit margin, so that this will constitute the premium to be paid by the insured.

In this respect environmental liability insurance is obviously not different from any other type of insurance; for these general principles we can hence refer to the insurance economics literature. However, it is important to stress that to make accurate premium calculation possible, one crucial element in insurance is, as we have just indicated, precise information on the probability that a certain loss will occur and the possibility to make a more or less accurate estimate of the potential magnitude of the damage. This is not only necessary in order to make an accurate estimation of the premium to be charged, but also to calculate the magnitude of the reserve to be set aside in case the accident for which insurance coverage was sought, occurs.

A conclusion of this simple introduction to the working of liability insurance is that an insurer needs information concerning the probability (p) that a certain event (the fact that the insured will be held liable) will occur and he or she will need information on the possible magnitude of the damage (D). The multiplier of these ( $\mathrm{p} \times \mathrm{D})$ constitutes the fair premium in actuarial terms. The reason the insurer can take over this risk is the law of large numbers: a larger group of insurers with a similar risk can be brought together in a risk group and thus risk spreading becomes possible.

If the insurer ideally has ex ante perfect information on the predictability of the probability and the magnitude of the damage, we call the particular risk insurable. It is precisely on the basis of statistics that the insurer will acquire information on the likelihood that the risk will occur with a particular insured; statistics may also provide information on the possible magnitude of the damage. Both these requirements may, however, be a problem in the case of environmental (liability) insurance. Several elements may negatively influ- 
ence the ex ante predictability of the risk. ${ }^{52}$ The ex ante information on the predictability of the risk is often low, given the relatively new character of environmental risks. Reliable statistics may sometimes be missing both with respect to the probability of the event occurring and with respect to the damage. ${ }^{53}$ Hence, there may not be a 'law of large numbers' to be applied. This obviously is not only a problem for environmental insurance, but occurs in every case where insurers are confronted with new risks, where reliable data may be missing.

The predictability of the liability risk is obviously a crucial element to guarantee the insurability of environmental liability. The question therefore arises whether the predictability of the liability risk can be increased, even in the absence of reliable statistics, or whether 'hard to predict risks' should be judged as uninsurable. The literature has indicated that uncertainty concerning the probability or the damage is of course an element which the insurer can in principle - take into account ex ante. If there is uncertainty, because of a lack of reliable statistics, this should not necessarily lead to the conclusion that a particular risk is uninsurable. We are then dealing with the concept referred to as 'insurer ambiguity' addressed by Kunreuther, Hogarth and Meszaros. ${ }^{54}$ They argue that the insurer can react to this uncertainty concerning either the probability of the event or the magnitude of the damage by charging a socalled risk premium to account for this unpredictability. Hence, an insurer can in principle also deal with a 'hard to predict' event, by charging an additional premium. Although theoretically the additional risk premium is hence the answer to insurer ambiguity, in practice the insurer will at least need some information to make more than an educated guess concerning the risk premium to be charged. Moreover, given the fact that an insurer is to be found in a competitive environment, market forces may well force the insurer to engage in liability insurance even when an appropriate risk premium cannot be charged.

The conclusion at the normative level is that the policy-maker should obviously make the scope of liability ex ante as clear as possible. In other words: the legislator should try to avoid legal uncertainty which may endanger insurability. ${ }^{55}$

52 Monti rightly points out that there may be both factual and legal uncertainty (Monti 2001, pp. 59-62).

53 Rogge 1997, p. 4.

54 Kunreuther, Hogarth and Meszaros 1993, pp. 71-87.

55 See Monti 2001, pp. 59-62. 


\subsection{Capacity}

We have already mentioned that a requirement for insurability is that the insurer should have ex ante information on the predictability of the risk and on the magnitude of the damage. So far we have dealt with the importance of the predictability of liability. However, the magnitude of the harm may also constitute a problem. ${ }^{56}$ There may be uncertainty as far as the possible magnitude of the harm is concerned. The insurer may react to this uncertainty by providing for an adequate reserve to be able to provide coverage for the environmental damage once it occurs. However, in many cases the expected loss may exceed the possibilities of the individual insurer. In that case the insurer can use various traditional insurance techniques to cope with this capacity problem. One possibility is to insure a similar risk jointly with a few insurers (so-called coinsurance); another possibility is reinsurance. One other solution which is often used in case of environmental liability insurance is pooling of capacity by insurers. In many countries insurers have shared risks in mutual pools on a noncompetitive basis to be able to provide coverage, also for risks with a relatively high potential magnitude. This is typically the case for the nuclear risk.

Generally legal doctrine has pointed to the fact that the possibilities to insure large risks have increased as a result of changes in the insurance industry. One effect of creating a European internal insurance market has been that the size of insurance markets (and hence the capacity) has considerably increased. ${ }^{57}$ Notwithstanding all of these possibilities to increase the capacity, the liability risk may be such that it can reach the limits of insurability.

\subsection{Risk Differentiation as Remedy for Moral Hazard and Adverse Selection}

As is well known from economic theory, insurance can always be endangered as a result of moral hazard or adverse selection. The appropriate remedy for both phenomena is risk differentiation. It follows from the economic principles of liability insurance that an adaptation of the policy conditions to the individual risk is essential to control both moral hazard and adverse selection. George Priest has claimed that the adverse selection problem has caused an insurance crisis in the United States and that it can only be cured by an appropriate differentiation of risk. ${ }^{58}$ If the insurance policy requires preventive

$56 \quad$ See Rogge 1997, pp. 3-4.

57 Cousy 1995, pp. 227-241

58 Priest 1987, pp. 1521-1590. Priest has been criticized by Viscusi, who claims that there were other reasons for the product liability crisis in the US than adverse selection on its own (Viscusi 1991, pp. 147-177). 
action from the insured party and provides for a corresponding reward in the premium, this should give optimal incentives to the insured for accident reduction. Thus risk pools should be constructed as narrowly as possible so that the premium reflects the risk of the average member of that particular pool. ${ }^{59}$

Considering the current practice of many European insurers, especially as far as the liability risk of enterprises is concerned, one is struck by the fact that so little use is made of the possibilities of risk differentiation. In that respect we specifically refer to the insurance of the risks of enterprises in the Netherlands where premiums merely depend on the turnover of a company and almost no individual differentiation takes place. ${ }^{60} \mathrm{Up}$ to now, one lump-sum premium has been charged for a whole variety of risks from environmental liability to occupational health. Such a global tariff for a whole variety of different risks obviously does not correspond to the economic need for individual risk differentiation. This system might have worked in a legal system where liability law was not used as the main source for compensating victims. But now that governments in Western Europe are increasingly withdrawing from social security systems, victims may need to use the tort system more often. ${ }^{61}$ This will inevitably force insurers into more effective risk differentiation.

The insurer can of course rely on existing mechanisms to control the 'ecological reliability' of the insured. In this respect one should not forget that most insureds in the case of environmental risks are licensed operators. Hence, an absolute minimum would be that the insurer checks whether the insured operator in fact possesses a valid licence. In addition the insurer could expressly require in the policy conditions that the operator follows the conditions of the licence and could even make insurance coverage dependent upon that. ${ }^{62}$ In other words, the insurer could make use of the fact that a decision concerning the way to reduce environmental harm has already been made by the administrative agency and possibly been laid down in the administrative licence. This is, by the way, current practice in Belgian environmental liability insurance. Many insurance policies stipulate that there would be no coverage in a case where the damage resulted from a violation of regulatory norms. ${ }^{63}$

Obviously, we should refer to the argument made above that following regulatory standards is, from a perspective of tort law, often merely a minimum. If socially efficient care is higher than the regulatory standard the potential polluter may be held liable, even in case of regulatory compliance. However, from the insurer's perspective it seems useful to rely at least on

\footnotetext{
59 Abraham 1988, pp. 949-951.

60 See Faure and Hartlief 1996a, pp. 140-150.

61 See Faure and Hartlief 1996b, pp. 254-259.

62 See also Kunreuther and Freeman 2001, p. 316.

63 Rogge 1997, pp. 28-29.
} 
regulatory standards, even though they may not always constitute the optimal norm and even though the insured may be held liable even though regulatory standards were met. Compliance with regulatory standards is, in other words, a minimum which an insurer could require. But other techniques should be used as well to control whether the insured could have taken more cost-effective prevention measures than the ones required by regulation.

Notwithstanding all these instruments which the insurer theoretically posseses to check the ecological liability of a firm, there is of course one element of uncertainty that can hardly be excluded by an insurer, which is the legal uncertainty following from the liability system. Although the ecological performance can be monitored, for example through eco-audits and other instruments, the insurer will not know ex ante how the judiciary may interpret for example the specific duty of care of a risk creator. Given the relatively new character of environmental liability many insurers still consider that the precise content of the scope of environmental liability is still uncertain. This not only endangers the predictability of the risk (see 6.1), but of course makes an adequate risk differentiation more difficult as well. There are more particularly several tendencies in legislation and case law concerning environmental liability which often cause nightmares to insurers: shifting the risk of causal uncertainty, joint and several liability as well as retroactive liability.

\subsection{Shifting the Risk of Causal Uncertainty}

A major problem with environmental damage, and also with so-called toxic torts, ${ }^{64}$ is that an exposure to some environmental harmful activity may cause a certain disease, but the particular disease may have been caused through other causes as well. In these cases the identity of the victim is certain, but there is uncertainty about who the injurer is. Indeed, the victim may well have got the disease from some background risk and not from the presence of, say, a nuclear power plant. ${ }^{65}$ Such questions have indeed arisen both in Belgium and in the United Kingdom. Causal uncertainty played a role in the famous British Sellafield case, where an English court had to decide on the causal relationship between childhood leukaemia and the nearby presence of a nuclear power plant at Sellafield. ${ }^{66}$ Similarly, Belgian courts have been confronted with the question of whether the physical complaints of inhabitants of the community of Mellery in the Walloon Region were caused by emissions from a nearby waste site. ${ }^{67}$

\footnotetext{
64 Trauberman 1983, pp. 177-296.

65 Estep 1960, pp. 259-304; Van 1994, pp. 109-118 and Van 1995, pp. 145-154.

66 Gardner 1990, pp. 423-434.

67 For a discussion of that case, see Lavrysen 1995, pp. 219-243.
} 
The danger of shifting the burden of causal uncertainty to the enterprise is that the insurer of the specific employer or producer will be required to compensate for damage which, on the whole, had probably not been caused by the insured party. ${ }^{68}$ In many countries an all or nothing approach is followed to causal uncertainty or a so-called threshold liability. That means that when the probability that the activity caused the loss is higher than a certain threshold (usually 50 per cent) ${ }^{69}$ the risk taker will have to compensate for the total loss. In other cases the burden of proof is shifted to the enterprise which will then mean that the enterprise will have to prove that the activity did not cause a particular damage, for instance cancer. In those cases the enterprise may end up paying to a large extent for damage that could never have been caused by its activity.

This perverse result could be avoided through a proportionate liability rule, such as a market share liability in product liability cases. This proportionate liability rule has been defended by several American scholars and is also defended in the economic analysis of law. ${ }^{70}$ The negative consequences of causal uncertainty could then be limited. A proportionate liability rule is less rigorous than the all or nothing approach of the reversal of the burden of proof. ${ }^{71}$ The proportionate liability rule would indeed mean that all victims can claim a proportion of their damage equal to the amount by which the power plant contributed to the loss. Thus the exposure to liability of the enterprise corresponds precisely with the amount to which the power plant contributed to the risk. ${ }^{72}$

Unless a proportionate liability rule is followed, it is not possible to cover a risk if that would mean that the insurer would not only cover the damage of its own insured parties but also the damage that might possibly have been caused by another party. These tendencies lead to a liability of enterprises for risks that they have not caused themselves (in the case of causal uncertainty) or for risks that were not foreseen at the time when the tort was committed (in the case of retrospective liability). They are largely caused by a hidden redistributive agenda: the wish to provide victim protection no matter what it may

\footnotetext{
68 Also Abraham 1988, pp. 959-960 and Katzman 1988, pp. 89-90. See also Bergkamp 2000a, pp. 154-155.

69 It is often expressed that it must be 'more probable than not' that the activity caused the damage.

70 Rosenberg 1984, pp. 851-929; Shavell 1985b, pp. 587-609. The Dutch Attorney General Hartkamp defended a market share liability in the DES case (Hartkamp 1992, pp. 241-258). In addition Spier pleaded in favour of a proportionate liability for latent diseases in his inauguration address (Spier 1990), as did Akkermans (1997) in his dissertation.

71 See Brüggemeier 1991, pp. 88-91.

72 Robinson 1985 , p. 798.
} 
cost. These tendencies may be far more problematic from an insurability point of view than the shift towards strict liability itself. Indeed, whereas strict liability as such is insurable, this is no longer true if retrospective liability is introduced or the risk of causal uncertainty is shifted to the enterprise.

Also these features, which deviate from the principle that an injurer can only be held liable for the damage he or she has caused, may lead to difficulties when it comes to insuring environmental liability. Several of these deviations can, however, be noticed precisely in the area of environmental liability.

\subsection{Joint and Several Liability}

One is an area which is closely related to the issue of causal uncertainty just discussed. It is the tendency to hold joint tortfeasors jointly and severally liable for all the damage to which their behaviour might have contributed. The reasons for doing so are well known. For the victim it is often difficult to prove a clear causal link with the actions of one particular polluter. This may sometimes lead to alleviations of the burden of proof or to holding several insurers jointly and severally liable. The often debated superfund regime under the Comprehensive Environmental Response, Compensation, and Liability Act (CERCLA) is an example of such a joint and several liability regime.

The effects of a joint and several liability are obviously also that the risk of insolvency is shifted to the injurer who will be sued by the victim. Indeed, joint and several liability means that the victim can claim full compensation from one injurer which then can exercise a redress against the other parties which contributed to the loss in proportion to their contribution. If, however, the other parties were all insolvent, the one injurer which was the defendant will have to compensate for the total loss, also for the losses it has not caused. In addition, the risks of uncertainty concerning the causal link are, under joint and several liability, also shifted to the one injurer which is sued in the particular case. The victim can suffice with suing just one of the many potentially liable insurers and claim full compensation. If the one injurer does not succeed in proving that others contributed to the loss, the damage will ultimately fall on the one injurer.

From an insurance perspective, joint and several liability may be dangerous for the simple reason that the insurer is then no longer merely insuring the risk posed by its individual insured (which it can still control), but also the risk caused by all the others. ${ }^{73}$ The welfare losses resulting from such a system of joint and several liability may be large. This mutual monitoring may ex ante not always be possible and the transactions costs involved (also in the systems

$73 \quad$ See Cousy 1995, p. 235. 
of redress) can be huge. Hence, on balance it is doubtful that joint and several liability will have positive incentive effects. The insurance effect is obviously, as the case of causal uncertainty illustrated, that an insurer will be held liable for the risks that its insured never caused. This tendency towards joint and several liability seems therefore to endanger the insurability. ${ }^{74}$

\subsection{Retrospective Liability}

There are, moreover, some other specific features of environmental liability insurance discussed in the literature which make it difficult to apply traditional insurance principles to environmental liability. One of these aspects, often stressed, is that liability insurance traditionally provides for coverage of accidents, meaning a sudden event, whereas in environmental liability there is often a long time lapse between the emission and the occurrence of the harm. Moreover, many of the pollution cases are not sudden events, but evolve gradually. This causes many technical problems, for example relating to the question when the damage actually occurred. These and other questions relating to the application of insurance principles on environmental liability are extensively discussed in the literature. ${ }^{75}$ One particular aspect of the potential long time lapse between the wrongful event and the damage is that this may result in retrospective liability. Retrospective liability is not only inefficient as far as giving incentives for accident prevention is concerned, but also leads to uninsurability. ${ }^{76}$

Let us, before showing why retrospective liability is insurable, once more come back to the requirement of foreseeability as a basis for insurability. We have already briefly discussed this in the context of predictability. It is important to stress that, apart from exceptional situations, there should be no reason to argue that there is uninsurability of environmental liability as long as the present-day insurer can see a growing liability threatening its position and can adjust its policy conditions accordingly.

The question whether a change in the liability regime therefore leads to uninsurability when this is applied in a retrospective manner can be relatively easily answered.

At first sight one could argue that this certainly is the case. If the insurer were not aware that the behaviour of this insured party might potentially have been considered wrongful, no premium would have been charged for this risk,

74 Monti 2001, p. 58. And see Bergkamp 2000a, p. 154 who argues that under joint and several liability civil liability becomes unpredictable and hence uninsurable.

75 See, e.g. Bocken 1992, pp. 284-327; Bocken 1993; Bocken and Ryckbost 1991 and see Cousy 1995, pp. 237-239.

76 For formal proof of this statement, see Faure and Fenn 1999, pp. 487-500. 
no preventive measures would have been required in the policy conditions and no reserves against losses would have been set aside. Indeed, insurance assumes that the insurer covers future risks which are at least to some extent foreseeable. Insurance requires some degree of predictability. However, the mere fact that insurers of, say, industrial waste disposal sites in the 1960s have - as a matter of fact - not foreseen that the activities of their insured parties could lead to a liability in the future, does not make this event totally unforeseeable. The potential of a change in the scope of liability is an uncertain element which the insurer can - in principle - take into account ex ante. We are dealing here with the concept of 'insurer ambiguity' addressed by Kunreuther, Hogarth and Meszaros. ${ }^{77}$ If insurers could foresee the likelihood of a possible change in the liability system, they could react to uncertainty by estimating the probability that this event would occur and charge an additional risk premium to account for this legal uncertainty. In sum, in an ex ante perspective one can argue that nothing is totally unforeseeable or unpredictable; insurers can in principle cope with 'hard to predict' events such as the introduction of retrospective liability by charging an additional premium. However, in an ex post perspective this message is not very helpful for insurers which, at the time, did not take this risk into account and now have to provide cover to enterprises for risks which the insurers considered apparently unforeseeable. Hence, no additional premium was charged and no reservations were made, which explains why the retrospective liability now laid down, say, for soil clean-up costs, leads to major problems for insurers. ${ }^{78}$ There is, hence, no problem of the uninsurability of retrospective liability as such, but only the simple fact that insurers did not take these risks into account when the policy was drawn up.

From the above it follows that real retroactive liability, where any change in the law was not foreseeable, will pose problems for insurers. Also insurers argue in their publications that liability for past pollution is uninsurable. ${ }^{79}$ Our theoretical analysis supports this claim. However, the problem of a long time lapse between the wrongful event (for example the emission of a toxic substance) and the damage will obviously often happen in environmental insurance.

\subsection{Summary}

We have tried to sketch briefly some conditions of insurability and relate them to the literature on environmental liability insurance. The lesson from this

77 Kunreuther, Hogarth and Meszaros 1993, pp. 71-87.

78 See Zeckhauser 1996, p. 5, who argues that retrospective liability may affect the predictability of risks; and see Abraham 1988, pp. 957-959.

79 For Belgium, see e.g. Rogge 1997, p. 6. 
literature seems to be that environmental damage can in principle also be covered through liability insurance. However, many conditions need to be fulfilled in order to apply classic liability insurance to environmental damage. From a theoretical perspective one could notice that the predictability of the liability risk may be difficult, given the many uncertainties in the legal system. In many countries the content of the environmental liability regime is still so uncertain that the liability risk is still hard to predict for injurers. That uncertainty will of course hardly be removed with Directive 2004/35/CE given the fact that its scope of application is rather limited and that it comes on top of national law dealing with the same issue. Uncertainties that would exist in national law thus remain. Also the potentially large scope of environmental disasters may outweigh the capacity of an insurer, even when remedies like pooling, co-insurance and reinsurance are used.

Insurers particularly seem to fear the 'difficult-to-predict' nature of environmental liability since it may endanger their possibilities of an adequate risk differentiation. The latter is again necessary to cure the problems of moral hazard and adverse selection. Insurers more particularly dislike the environmental liability risk since it has what is often referred to as a 'long-tail' character. They fear to provide cover today for damage with a cause in a very distant past. It is precisely this long-tail character of many environmental risks that according to insurers endangers the predictability and thus the 'manageability' of the environmental liability risk.

The core problem is undoubtedly that environmental damage is not a classic accident, being a sudden event which is the normal object of liability insurance. Environmental damage has to the contrary a gradual nature. This can lead to important problems in the insurance context related for example to the question when liability precisely was created.

Moreover insurers will be confronted often with the risk that courts, being confronted with a case of environmental damage, will often seek the deep pockets of risk creators or (preferably) their liability insurers. This may lead to a shift in the burden of proving causation, to imposing joint and several liabilities and even to applying liability rules in a retrospective manner. Insurers have often argued that especially these characteristics of many environmental liability regimes may endanger the insurability of environmental liability. We have shown that from a theoretical and insurance technical perspective there is some support for this claim.

Within the perspective of the central line of this chapter, where we examine whether liability insurance could fulfil a compensatory function, we have to conclude that this is only the case to a limited extent. It is precisely because of the reasons we have discussed that in practice many alternatives to liability insurance have been developed of which it is thought that they might better be able to provide financial cover (and thus guarantee compensation) 
than traditional liability insurance. Some of these alternatives are still rather novel in the sense that there is not much experience with them yet. This is for instance the case for the use of capital markets and new financial instruments to cover environmental risks; with others there is already more experience. This is for instance the case with risks sharing agreements. The oil pollution risk has for many years been covered through the so-called Protection and Indemnity clubs (P\&I clubs) which function as a mutual insurance company. ${ }^{80}$ One particular alternative to liability insurance which seems particularly interesting is the shift away from liability insurance towards first-party and direct insurance schemes. These are particularly interesting since insurers have in some countries, more particularly in the Netherlands, advocated the use of these first-party and direct insurance schemes, arguing that any of the problems that arise in covering environmental liability play less of a role when environmental damage is covered on a first-party basis. Hence this new tendency, which seems to receive attention in many other countries as well, deserves some attention.

\section{ALTERNATIVE COMPENSATION MECHANISM: ENVIRONMENTAL DAMAGE INSURANCE}

\subsection{Theory}

There is another alternative which may compensate victims of environmental damage, which is now sometimes advocated, and that is first-party insurance. Liability insurance is a third-party insurance, whereby the insurer covers the risk that its insured (the potentially responsible party) will have to compensate a third party. A first-party insurance is a system whereby the compensation is awarded directly by the insurer to the victim. Whether such a first-party insurance can be considered as an efficient alternative for third-party liability cannot be answered in general terms. It depends to a large extent on the details of such a system and more particularly on the question whether the first-party insurance is combined or not with the liability of the potentially responsible party.

The underlying principle in a first-party insurance is that the insurance undertaking - in principle - pays as soon as damage occurs, provided that it can be proven that the particular damage has been caused by the insured risk.

80 For an overview of alternatives to liability insurance, see Faure 2004, pp. 455-489. 
Payment by the insurance undertaking occurs irrespective of the fact whether there is liability. The arguments advanced in the literature in favour of firstparty insurance are that the transaction costs would be lower and that risk differentiation might be a lot easier. ${ }^{81}$ The reason is simply that with first-party insurance the insurer directly covers the risk of damage with a particular victim or a particular site. The idea is that it is therefore much easier for the insured to signal particular circumstances which may influence the risk to the insurer. The problem with liability insurance is that the insurer is always insuring the risk that its insured (the potential injurer) will harm a victim (a third party) of which the properties are unknown ex ante to the insurer. Moreover, under liability insurance there are lots of uncertainties, for example how the judge will interpret this specific liability of the insured. In the ideal world of first-party insurance the insurer directly covers the victim, e.g. the risk. The insurer can therefore directly monitor the risk and in principle provide a much better risk differentiation.

Obviously lots of practical questions arise when it comes to the application of the ideal model of first-party insurance to environmental harm, such as damage to biodiversity or soil pollution. One question is under what kind of circumstances the insurance will be triggered if liability is not required. Does damage suffice and, if so, how is damage to be described? Moreover, also in a first-party insurance scheme the question will have to be answered as to who finances the system. In an ideal theoretical world, it would be the victim who finances a first-party insurance. That would obviously constitute a major difference from liability insurance. Immediately one can understand that there would be opposition to a first-party insurance scheme since under this condition it might violate the polluter pays principle. However, one could also imagine a first-party insurance scheme whereby it is the one who possesses the particular site (which could be the polluter, but that might not necessarily be the case) who pays the premium. In that hypothesis one usually refers to it as 'direct' insurance instead of first-party insurance.

Finally, also under a first-party insurance scheme, the relationship to liability law will have to be clarified. One question is whether a first-party insurance system would replace the liability system. That would obviously be a far-reaching solution whereby the liability system would be totally set aside. It would mean that the victim would receive compensation directly from the insurer simply by proving that a certain damage has been caused. But then inevitably the question would arise as to how potentially responsible parties would still have incentives for prevention without a liability system. Therefore one can assume that a first-party insurance system would not replace liability

81 This argument is especially advanced by Priest 1987, pp. 1521-1590. 
law. But that then raises the question whether there would be an accumulation of liability and first-party insurance and whether that can be considered as efficient.

Moreover, the question arises as to what amounts would be paid under firstparty coverage. Usually the amounts paid in first-party insurance are lower than the full compensation which is in principle awarded under tort law. ${ }^{82}$

This shows that although first-party insurance might seem very attractive at first sight at the theoretical level, since it might better enable a narrowing of risk pools, still a lot of questions arise. It is probably best to examine these questions by looking at a practical example where a first-party insurance of polluted sites has been implemented.

Before doing so it is probably important to stress that this exposé of firstparty insurance is not merely theoretical, but does indeed have a certain practical relevance. Indeed, the general liability committee of the Comité Européen des Assurances (CEA) has executed a study on first-party legal obligations for clean-ups and corresponding insurance covers in European countries. ${ }^{83}$ This study shows that although the insurance situation between European countries still differs to a large extent, first-party insurance coverage seems to be available in several member states. ${ }^{84}$ In one country, namely the Netherlands, the insurers have deliberately chosen to provide coverage of polluted sites on a first-party basis. The idea is that the first-party coverage should replace the traditional environmental liability insurance. Hence, it seems sensible to take a closer look at the insurance situation in the Netherlands.

\subsection{First-party Insurance for Polluted Sites in the Netherlands}

\subsubsection{Dissatisfaction with existing coverages}

The starting point for the concern of the Dutch insurers was the fact that all the theoretical problems which we discussed in section 6 concerning the insurability of environmental liability had also played a major role in Dutch environmental practice. This had to do with the fact that environmental risk is the example of a 'long-tail risk' whereby the insurer today could be confronted with events which occurred in the distant past and would lead to liability of the insured now. Insurers held that this generally endangered the predictability of the risk.

82 Note, however, that under liability insurance the coverage provided will be linked to certain limits as well.

83 CEA, Study on first-party legal obligations for clean-ups and corresponding insurance covers in European Countries, Paris, CEA, 21 October 1998.

84 See the summary tables in the CEA study, above n. 83 at 32. 
Most of these problems were hence related to the fact that environmental harm does not constitute a sudden event, as is the case with most 'traditional' accidents insured under liability insurance.

The Dutch insurance market therefore used to have the environmental risk covered through a variety of insurance policies, of which the most important were:

- the liability insurance policy $(\mathrm{AVB})^{85}$ for sudden risks and for occupational health risks which were related to the environment;

- the environmental liability insurance (MAS) for risks of a more gradual nature, excluding personal injury; ${ }^{86}$

- fire insurance for clean-up costs after fires (although the precise coverage of that policy was debated).

This environmental liability insurance was provided by an environmental pool, referred to as MAS. ${ }^{87}$ In this MAS 50 (re)insurers work together to cover the environmental liability risk. The MAS was hence constructed as an environmental pool, although the individual insurers connected to the MAS contracted individually the MAS policy under their own label.

There was, however, a lot of criticism of that system, which can be summarized as follows.

First of all the whole division of coverage between the AVB and the MAS was based on the idea that the AVB would cover the sudden risks and the MAS would cover the risks of a more gradual nature. As is well known, in practice it was not always possible to make a clear distinction between sudden and gradual risks, which led to uncertainties concerning the scope of the coverages of both policies. This was obviously the result of the fact that the Dutch insurers did not decide to exclude the environmental risk altogether from the traditional liability insurance of companies (AVB). ${ }^{88}$

The environmental liability policy (MAS) was considered to be rather complicated and had a very complicated procedure towards accepting insureds. The policy was also rather expensive and hence difficult to sell.

A further problem was that neither the general environmental liability policy (AVB) nor the environmental liability insurance policy (MAS) provided any coverage for damage caused to the insured's own site. This caused a problem for insureds since according to the case law of the Dutch Supreme Court companies could be held liable also for pollution of their own

\footnotetext{
85 Aansprakelijkheidsverzekering bedrijven.

86 See on that policy, Wansink 1985, p. 98.

87 Milieu-aansprakelijkheidsverzekering Samenwerkingsverband.

88 For further details on these difficulties, see Wansink 1997, pp. 451-460.
} 
site. In addition, the fact that pollution caused to the site of the insured was not covered inevitably again caused uncertainty concerning the scope of coverage. One could imagine cases where polluted groundwater went from the site of the insured to a neighbouring site. This would cause problems since the pollution of the site of the neighbour would be insured whereas the pollution of the insured's own site would not.

Furthermore, there were more uncertainties concerning the question whether clean-up costs were covered under the fire insurance policy. The fire insurance policy covers the clean-up costs after fire as well as any environmental damage that occurred, but only on condition that there was a prior fire. In the fire insurance policy no account was taken of the fact that after a fire serious soil and water pollution could also occur. It was not always clear whether the soil clean-up costs resulting from the fire were also covered under the fire insurance.

Finally there were obviously all the traditional problems related to environmental liability, such as the question whether specific damage was indeed caused as a result of an insured risk. Also case law concerning environmental liability extended in a way which was hardly foreseeable for insurers. Hence, the liability risk was increasingly considered unpredictable and thus uninsurable as far as environmental harm was concerned.

\subsubsection{Environmental damage insurance: main features}

This led the Dutch insurers association to present in 1998 a new product, the environmental damage insurance (MSV ${ }^{89}$ ). This policy has been available since 1 January 1998 and takes a radically different approach from traditional environmental liability insurance. ${ }^{90}$

This new environmental damage policy provides for various new elements. First of all it provides integrated coverage of all the environmental damage which occurs on or from the insured site. A prerequisite is that it concerns pollution of the soil or of the water. The integrated coverage means that the new environmental damage insurance replaces the traditional pollution insurance (for sudden pollution) in the AVB and the liability insurance of the MAS (for gradual pollution).

The whole idea is that this coverage constitutes a direct insurance. In other words, the insured site is insured, even when the costs of clean-up have to be met for the site of a third party. Coverage takes place as soon as the insured site is polluted as the result of the insured risk, irrespective of the fact that the insured could be held liable for the damage or not. In some cases the third

89 Milieuschadeverzekering.

90 For a good description of the new policy, see Wansink 1999, pp. 77-82 as well as Janssen 1998, pp. 111-112 and Drion 1998, pp. 19-21. 
party (the victim), moreover, receives a direct action on compensation on the basis of the environmental damage insurance policy. The trigger for compensation under this policy is therefore no longer tort law, but the insurance policy as concluded between the insured and the insurance company. This therefore typically is a first-party insurance or, as it is called in the Netherlands, a direct insurance. It is a direct insurance to the extent that it also benefits third parties. It is indeed not the third-party victim who purchases insurance (although the insured may be the victim), but someone who has responsibility for a site on or from which water or soil pollution may occur. The policy thus benefits third-parties as well, at least when this is provided in the policy.

Obviously the environmental damage insurance cannot set aside tort law, but the main advantage according to Dutch insurers is that the coverage is not triggered on the basis of liability. The advantage from the victim's point of view is obviously that coverage can be provided more rapidly and probably at lower transaction costs than through the court cases which are necessary as a result of liability law.

The environmental damage insurance as provided by the Dutch Insurers Association consists of several categories with different coverages. This obviously shows that first-party insurance better enables an optimal risk differentiation since every insured will be able to purchase insurance coverage according to its own preferences. The damage on the insured location itself is insured. This at least provides coverage for clean-up costs and this is rather broadly defined. Also costs for the repair of damage are included.

The insured remains in principle fully liable, although the third party (beneficiary) which would be protected under the new MSV policy could claim directly on the policy and would hence in principle not have an interest in using liability law. However, it might be that the insured has taken too limited coverage and that in that particular case the third party would still (have to) use liability law. In that case the liability itself is not covered (and an insolvency risk remains), but the MSV policy provides for legal aid assistance in a number of specific cases. This is the case if the sum which is insured under the MSV coverage is sufficient to pay for the clean-up costs incurred by the government. The same applies in the case where a third party would choose the liability law instead of direct action under the MSV policy. ${ }^{91}$

\subsection{Assessment}

The main feature of the new environmental damage insurance provided in the Netherlands is obviously that it is no longer a liability insurance, but only a

\footnotetext{
$91 \quad$ See Wansink 1999, p. 81.
} 
first-party (or direct) insurance. The advantage for the insurer (and for the insured) is that the difficult road of liability law is excluded. Whether liability law will still be used is uncertain. Third parties could still use liability law, although it is obviously easier for victims to use the direct action provided under the MSV policy, at least in those cases where it is provided for. ${ }^{92}$ There is, however, one important weakness which unavoidably remains, namely the fact that the environmental damage insurance is not compulsory. Hence, there may be situations where companies in the Netherlands have purchased no insurance coverage at all or situations where only a basic coverage was taken on for damage on the particular site, but not to a sufficient amount so that all damage suffered by third parties would be covered. In those cases, third parties claiming against the party responsible might still be confronted with an insolvent polluter. Moreover, the new MSV regime is exclusive, meaning that the coverage for (sudden) soil and/or water pollution has now been removed from the liability insurance policy. This means that if an insured only had taken an MSV coverage for the insured site and a loss occurred to a third party on another site, this third party would probably use liability law against the polluter. In that particular case the polluter cannot call on its general liability insurance (AVB) since the environmental risks have now been completely removed from that policy as a result of the entering into force of the MSV. ${ }^{93}$

But that can obviously hardly be considered a weakness of the system of first-party insurance: the insured obviously does not get more than he pays for. Since the MSV is a general policy with a lot of options for the insured, premiums and amount of coverage can vary. The type of costs which are insured are, however, identified in the general policy and according to the CEA study on first-party insurance the total amount of coverage available under this new environmental damage insurance in the Netherlands would be 25 million Dutch guilders (11 344505 Euros).

\subsection{Evaluation}

According to information provided by the Dutch Insurance Association, this new product works remarkably well. It claims that the interest of enterprises in this new environmental damage insurance is much larger than in the traditional environmental liability insurance. Whether this new product is actually yet a success is more difficult to judge. There is, however, undoubtedly growing interest from industry for this new environmental damage insurance. The

92 The direct action of the third party must indeed be explicitly accepted by the insured.

93 Wansink 1999, pp. 81-82. 
fact that a wider financial security for environmental damage is provided in the Netherlands as a result of this product should definitely be considered as positive. Moreover from the victim's (mostly the government) perspective, the fact that the environmental damage insurance provides for direct action for victims should be considered as a positive as well. It also shows that it seems possible to provide financial security for environmental damage without many of the insecurities and dangers inherent in an environmental liability insurance system.

Moreover, the advantage for the insured is that under this environmental damage insurance, damage caused to its own site is also covered, which was obviously not the case under liability insurance. ${ }^{94}$ However, some company lawyers have been critical of this new insurance product. They argue that in practice insurers are so stringent in providing coverage that effectively only the very good risks would be able to receive coverage. ${ }^{95}$ Hence, they claim that one cannot blindly argue that environmental damage insurance is a remedy for all insurability problems concerning environmental risks.

If, at a policy level, one were therefore to conclude that a strict liability system should be combined with some form of guarantee that financial security is available, one should at least leave the option open to industry to provide this financial security via environmental damage insurance. The Dutch example shows that this first-party type coverage seems able to meet that end. ${ }^{96}$ Moreover, the example seems to be being followed in other countries as well. ${ }^{97}$

\section{REGULATORY STRATEGIES TO SUPPORT PRIVATE SOLUTIONS}

So far we have looked at private versus public solutions to environmental liability and this both from the perspective of prevention and compensation for environmental harm. As far as prevention was concerned we stressed that although the main role in preventing environmental harm will lie with regulation, there is

\footnotetext{
94 Cousy 1995, p. 240.

95 Niezen 1998, p. 114.

96 Bergkamp also argues strongly in favour of first-party and against environmental liability insurance (Bergkamp 2000b, pp. 112-114).

97 Ranson reports that in Belgium too a 'direct' environmental insurance is to be offered which would also cover gradual pollution (but would exclude ecological damage). See Ranson 2000, p. 68. The new policy would also cover, like the Dutch example, remediation costs. It is to be offered by AIG and would provide coverage of up to 1 billion BEF (24 789352.48 Euros) (see Kerremans 1999, pp. 537-583).
} 
still a task for environmental liability as well, especially to back up regulatory norms. As far as compensation is concerned we mainly addressed the role of private legal instruments, being tort law, liability insurance and alternatives like first-party and direct insurance. However, also as far as compensation is concerned, the dividing line between private law and regulatory solutions is not always that clear since, as far as promoting compensation is concerned, governments could play a role as well. The question indeed rises whether government can be of help providing facilitative strategies to improve the functioning of the private legal system. Again, this is an issue that has been addressed at great length in economic (and other) literature. Within this chapter, which aims merely at providing a tour d'horizon of the issues at stake, we just want to summarize this literature briefly by indicating what types of facilitative strategies could be followed and what the advantages and possible drawbacks of some of these strategies are.

\subsection{Compulsory Insurance?}

In the theoretical analysis provided in section 2 we made it clear that although there may be arguments in favour of strict environmental liability in cases where environmental harm can be considered unilateral, strict liability may cause underdeterrence in the case of insolvency. Hence, we have to consider carefully the risk that a potential polluter would simply choose a 'hit and run' strategy whereby he or she would pollute, irrespective of strict liability, since the strict liability rule could not affect him or her if he or she were insolvent. This risk of an 'orphaned' polluted site is obviously one reason why liability rules alone cannot suffice as a deterrent. Regulation is needed in that respect as well as has been shown in section 3 . In this section we will address the question whether insurance, as presented in section 6 , could remedy this risk. In section 6 we have explained how liability insurance generally works and which conditions have to be met to make the environmental liability risk insurable. The question however arises as to whether the benefits of liability insurance as sketched out in section 6 are so large that they warrant the introduction of compulsory liability insurance. ${ }^{98}$

One reason that could be advanced for introducing compulsory insurance would be information problems. These might arise in the case where the potential injurer cannot make an accurate assessment of the risk he or she is exposed to nor of the benefits of the purchase of insurance. An underestima-

98 If we refer to compulsory liability insurance here, this should be read as any scheme whereby the potentially responsible parties are forced to take out financial security. This may also take the form of a bank guarantee or a mandatory participation in a funding pool. 
tion of the risk would in that case lead to the wrong decision of the injurer not to purchase liability insurance. The legislator could remedy this information problem by introducing a general duty to insure. This information problem is probably a valid argument to introduce a generalized duty to insure for motor vehicle owners. Maybe the average driver of a car underestimates the benefits of liability insurance. If there were no information problem and the legislator nevertheless introduced a duty to insure because this would be 'in the best interest' of the insured, this would of course be mere paternalism.

Moreover, the problem with this information argument is that it is merely a reason to introduce regulation aiming at the provision of information (see section 8.3 below), but not necessarily an argument to introduce compulsory insurance. The major disadvantage is that one is not sure of the attitude towards risk of the various risk takers. For some, compulsory insurance may not increase their utility and thus not be beneficial.

Another reason to introduce compulsory liability insurance is the argument often used by lawyers, namely the insolvency argument. The argument goes that the magnitude of the harm will often exceed the individual wealth of an injurer, whereby a problem of undercompensation of victims will arise. Lawyers would, hence, push forward compulsory insurance as an argument to guarantee effective compensation to the victim. This - more distributional argument obviously may play a role in the context of environmental liability insurance as well. If an injurer were to be found judgment proof and hence a polluted site 'orphaned', the costs would be borne by society.

It is, however, also possible to make an economic argument that insolvency will lead to underdeterrence problems which might be remedied through liability insurance. Indeed, this so-called 'judgment-proof' problem has been extensively dealt with in the economic literature. ${ }^{99}$

Insolvency may pose a problem of underdeterrence. If the expected damage largely exceeds the injurer's assets, the injurer will only have incentives to purchase liability insurance up to the amount of its own assets. The injurer is indeed only exposed to the risk of losing its own assets in a liability suit. The judgment-proof problem may therefore lead to underinsurance and thus to underdeterrence. Jost has rightly pointed to the fact that in these circumstances of insolvency, compulsory insurance might provide an optimal outcome. ${ }^{100} \mathrm{By}$ introducing a duty to purchase insurance coverage for the amount of the expected loss, better results will be obtained than with insolvency whereby the

99 More particularly by Shavell 1986, pp. 43-58.

100 Jost 1996, pp. 259-276. A similar argument has been formulated by Polborn 1998, pp. 141-146 and by Skogh 2000, pp. 521-537. Skogh has also pointed out that compulsory insurance may save on transaction costs. 
magnitude of the loss exceeds the injurer's assets. ${ }^{101}$ In the latter case the injurer will indeed only consider the risk as one where it could at most lose its own assets and will set its standard of care accordingly. When the injurer is, under a duty to insure, exposed to full liability the insurer will obviously have incentives to control the behaviour of the insured. Via the traditional instruments for the control of moral hazard the insurer can make sure that the injurer will take the necessary care to avoid an accident with the real magnitude of the loss. Thus Jost and Skogh argue that compulsory insurance can, provided that the moral hazard problem can be cured adequately, provide better results than under the judgment-proof problem. This is probably one of the explanations why, for instance, compulsory insurance was introduced for traffic liability. Uninsured and insolvent drivers who have little money at stake which they may lose compared to the possible magnitude of accidents they may cause, may have little incentive to avoid an accident. Insurers might better be able to control this risk and could force the injurer to take care under the threat of being shut out of the insurance. Thus the insurer comes under a duty to insure the licensor of the activity.

Indeed, this economic argument shows that insolvency may cause potentially responsible parties to externalize harm: they may be engaged in activities which may cause harm which can largely exceed their assets. Without financial provisions these costs would be thrown on society and would hence be externalized instead of internalized. Such an internalization can be reached if the insurer is able to control the behaviour of the insured. As we have shown above, when discussing how risk differentiation can be applied to environmental liability insurance, the insurer could set appropriate policy conditions and an adequate premium. This shows that, if the moral hazard problem can be cured adequately, insurance leads to a higher deterrence than a situation without liability insurance and insolvency.

However, there are also serious drawbacks to introducing a duty to insure. One problem is that governments may become too dependent upon the insurance market. One should realize that if one makes the availability of insurance coverage a prerequisite for the operation of an enterprise, insurance undertakings in fact become the licensor of the industry, which may be questionable from a policy point of view. ${ }^{102}$ In fact the insurer becomes the 'environmental policeman'. ${ }^{103}$

A second issue is that compulsory insurance should only be introduced when competitive insurance markets can provide a sufficiently differentiated

\footnotetext{
101 See also Kunreuther and Freeman 2001, p. 316.

102 See Rogge 1997, p. 40.

103 See Monti 2001, p. 65. See also Bergkamp 2000b, pp. 112-114 who argues heavily against compulsory insurance.
} 
offer of insurance policies. From a policy view point it also seems highly problematic to make liability insurance compulsory in concentrated insurance markets. Indeed, in that case the inefficiencies in the insurance market would be reinforced by making the purchase of insurance compulsory.

A further problem is that the policymaker should equally realize that today liability insurance coverage for environmental harm is still a relatively young and inexperienced branch. In this respect we can refer to fact that risk differentiation in environmental liability insurance in Europe still stands at the beginning of its possibilities and that far more possibilities exist to relate policy and premium conditions in an appropriate way to the ecological reliability of firms. Hence, one can really question whether today insurance firms are yet able to differentiate environmental liability risks in such a way that one can argue that moral hazard can be controlled optimally on competitive insurance markets. The cure to these problems is obviously not to make a poorly functioning insurance system compulsory.

It shows, however, one probably important conclusion from this discussion on compulsory liability insurance. Although it may be important from a theoretical perspective to introduce a duty for the permit holder to secure appropriate means, it seems more appropriate to look for a flexible system whereby the licensing administrative authorities could judge in individual cases whether the obligation to provide financial security has been met. Such a system, whereby it is left to the administrative authorities to decide the form and amount of the financial obligation, seems more flexible and entails fewer of the risks and dangers of a generalized system of compulsory liability insurance.

There is some, although limited, experience in European countries with compulsory insurance. Compulsory insurance was introduced in the German environmental liability Act of $1990 .{ }^{104}$ Also, in chapter 33 of the Swedish environmental code, compulsory insurance has been introduced. Remarkably, as we have already mentioned above (in section 5.3), Directive 2004/35CE did briefly address the issue of financial security in Article 14 but left it to member states to take measures to encourage the development of financial security instruments. Given the fact that the directive at the same time introduces a strict liability for a great many activities, this solution seems rather weak.

\subsection{Compensation Funds?}

A question that inevitably arises when issues of environmental damage are discussed is whether traditional liability law, combined with insurance, is at all

104 The insurability policy used is discussed by Lang 1996, pp. 169-183. For an overview of the German system, see Richardson 2000, pp. 61-62. 
able to provide compensation for environmental damage. Issues of fault or negligence have been avoided in many legal systems by a trend towards strict liability. However, we have already indicated that strict liability alone will of course not guarantee compensation for environmental damage, given the insolvency problem. This will create a demand for insurance. However, it is well known that many problems may arise with the insurance of environmental damage. ${ }^{105}$ Therefore in many legal systems the question has been asked whether compensation for environmental damage should be provided through compensation funds. Well known in this respect is of course the United States Superfund, introduced through CERCLA, which has led to a lot of criticism. ${ }^{106}$ Also in several European legal systems pleas can be heard in favour of installing compensation funds to cover environmental damage. In the Netherlands this has been proposed in the literature. ${ }^{107}$ In addition the idea is now increasingly being introduced in policy documents in the various member states formulating proposals for the reform of environmental law. In this respect we can point to the Interuniversitary Commission for the Revision of Environmental Law in the Flemish Region that proposed the introduction of a compensation fund in the Flemish Region, ${ }^{108}$ and also to a Dutch study performed on behalf of the Ministry of the Environment proposing the introduction of an environmental compensation fund in the Netherlands. ${ }^{109}$ Hence, there are ample reasons to take a closer look at the phenomenon of compensation funds.

One cannot escape the impression that often - especially at the political level - funds are advocated as a miracle solution for all problems of environmental damage although no clear definition is given of the specific funds. This can be misleading since the term 'fund' is often used for a variety of private or public financial arrangements that may be quite different. ${ }^{110}$

From an economic perspective there are not many reasons why if both are - in theory - available, a compensation fund would provide better protection

105 See generally on the limits of insurability; Faure 1995b, pp. 454-462 and the discussion in section 6 of this chapter.

106 Interesting papers analysing Superfund can be found in Revesz and Stewart 1995.

107 See Kottenhagen-Edzes 1992, pp. 297-298; Hulst 1993; Knottenbelt 1990; Van 1994, pp. 109-118 and Van 1995, pp. 145-154.

108 See Interuniversitaire Commissie voor de Herziening van het Milieurecht in het Vlaamse Gewest 1995, pp. 943-985 and Bocken, Lambrecht, Boes, De Nauw, Faure and Lavrysen 1996, pp. 31-32.

109 Gilhuis and Verschuuren 1994, p. 3. For comments, see Hulst 1995, pp. 167-173 as well as De Putter and Verschuuren 1995, pp. 96-99.

110 An overview of various types of environmental funds is provided in Faure and Hartlief 1996c, pp. 321-326. 
against insolvency than the private insurance markets. One could assume that an insurer is better able to differentiate risks since an insurer is specialized in risk differentiation and risk spreading. Insurers therefore possess techniques to determine in what way their insured contribute to the risk. Obviously this assumes that the insurance markets are competitive. In the absence of competition on insurance markets, either the supply of insurance coverage could be too limited or premiums could be excessively high, which could justify a preference for a compensation fund. ${ }^{111}$ But if insurance markets are competitive, insurers can be assumed to be better able to deal with classic insurance problems such as moral hazard and adverse selection than the administrators of a compensation fund. One cannot see as a matter of principle why a government agency that would run a compensation fund would have better information on risks than an insurer. This might, however, be different if highly technical risks are involved where operators of certain facilities are in a much better position than the insurance company to monitor each other. This point has been made for instance concerning the compensation for nuclear damage. One could argue that a risk-sharing agreement between nuclear plant operators could lead to optimal monitoring between the operators since they possess much better information on prevention, and good and bad risks than an insurance company would. ${ }^{112}$ Also in maritime insurance the Protection and Indemnity Clubs, which we have already discussed and which are based on a mutual risk sharing between tanker owners, play a crucial role. ${ }^{113}$

So far we have outlined that in general there are very few reasons to expect that a compensation fund would provide better compensation than a private insurance market. This does not mean, however, that there may be no role at all for compensation funds with respect to environmental damage. However, most fund solutions typically refer to the situation that a polluter cannot be identified or is insolvent. ${ }^{114}$ A compensation fund may well be used to guarantee compensation in case of insolvency of the injurer or the insurer. In that case a fund does not replace the liability and insurance system, but only intervenes in a particular case when the injurer or the insurer were found to be insolvent. This combined use of the liability system, insurance and a guarantee fund for the insolvency risk has the advantage that the incentives of the liability system will remain untouched and that the fund will only have to intervene in the event of insolvency. ${ }^{115}$

\footnotetext{
111 Faure and Van den Bergh 1995, pp. 65-85.

112 See Faure and Skogh 1992, pp. 499-513 and Faure 1995a, pp. 21-43.

113 See Coghlin 1984, pp. 403-416.

114 See e.g. Smets 1997 , pp. 223-248.

115 This combined approach is also proposed by Monti 2001, pp. 65-68.
} 
However, the question arises whether such a fund could at all be used separately from compulsory insurance (in the broadest sense). Indeed, if insolvency of the injurer is the problem one fears, it seems more logical to discuss the introduction of a duty to insure instead of immediately advancing a fund solution.

Many phenomena that include a private or public compensation scheme for environmental damage are referred to as 'fund' solutions. We took a brief look at some of these solutions, comparing them to traditional liability and insurance. Generally insurance seems better able to control risks and can be provided at lower costs. It seems therefore more appropriate to use traditional liability and insurance as far as possible and to use funds only in cases where insurance markets fail and there is reason to believe that funds would be able to provide adequate compensation. In that respect a guarantee fund comes to mind to provide coverage if an insurance company were to go out of business. However, it does not seem useful to introduce a guarantee fund without a corresponding duty to insure.

\subsection{Other Approaches}

Of course governments could do more to facilitate the provision of compensation and the well functioning of private law and insurance markets than merely introducing a duty to ensure or a compensation fund. First of all government could structure liability law in such a way that insurability is promoted. Thus shifting the risk of causal uncertainty to the injurer and introducing retrospective or joint and several liabilities should be avoided. There are, in addition, also examples of governments which actively intervene to provide financial guarantees themselves on which potential risk creators can call. Too often one has the impression that when insurance or financial markets do not function optimally the government immediately intervenes with public funds. It seems perhaps that there is a need to investigate whether other facilitative strategies could be used to promote the functioning of private law and insurance markets.

In that respect one can also point at the importance of an effective competition policy. There have indeed been some examples (more particularly as a result of pooling in nuclear liability insurance and marine insurance for oil pollution damage where a very close co-operation between insurers took place) whereby the compatibility with insurance policy was doubtful. It may be clear that insurance markets can only function effectively and offer a wide spectrum of differentiated insurance policies when this is supported by an effective competition policy. However, in some cases it may equally be needed for insurers to co-operate, for example to acquire information on specific new (environmental) risks. In those cases this co-operation can increase the insur- 
ability of particular risks. The same may in some cases be true with pooling as well. In some cases pooling of risks between insurers can create insurance markets (for example for large catastrophic risks) where without the pooling the risks may simply be uninsurable. In all of those cases where co-operation is necessary to increase the insurability of the risk, competition authorities will nevertheless have to be extremely careful and watch that this co-operation does indeed lead to the desired benefits for society and does not create the adverse effect of rather reducing than increasing the insurability of particular risks.

Finally one can also point at the importance of information strategies. Indeed, we have already indicated that particular risk creators (or potential victims) may be insufficiently informed of the environmental risks that they are exposed to. It could then be considered as a task of government to provide informational strategies whereby both injurers and potential victims are informed of the risks they are exposed to, of the availability of insurance or other financial means to provide protection against these risks and of the benefits this may generate. Hence, these facilitative information strategies may cure an information asymmetry and can thus equally remedy a potential market failure.

At the same time one equally has to warn that as soon as governments are asked to intervene there is always the danger that private interest may play an important role. As a result of private interest one can for instance notice that with the argument that this should promote insurability in some areas of environmental liability (notably oil pollution and nuclear liability), many governments have (as a result of international conventions) put a financial cap on the liability of risk creators. These financial caps or limits are largely considered inefficient (since they lead to underdeterrence) and of course limit the available compensation to the victim. ${ }^{116}$ This example shows that one has to be very careful that governments are not captured by business interests and as a result create inefficient regulatory solutions (like financial caps) under the pretext that this will promote insurability of risks.

\section{HARMONIZATION}

\subsection{Starting Point}

A crucial question is whether there should be any harmonization of the issues addressed in this chapter and more particularly of environmental liability.

116 For critical analysis of financial caps, see inter alia Faure 2003, pp. 194-206. 
Again this question can be addressed taking into account the rich economic literature that has been dealing with the subsidiarity principle and its application to environmental harm. This is also an issue that has been dealt with extensively in the economic literature. ${ }^{117}$ We can thus largely refer to this literature and briefly summarize the way in which economists would view the federalism debate, applied to environmental liability.

The starting point for economists is that a competition between legal orders will lead to a locative efficiency in the provision of legal rules if certain specific conditions are met. From this starting point it is argued that, from an economic point of view, decentralization should be the starting point. Thus the central question becomes: why centralize? Although decentralization thus has the preference (since the decision maker as close as possible to the citizens will have the best information on what is optimal for the citizens concerned) several criteria for centralization are advanced as well.

\subsection{Transboundary Externality}

A first reason for centralization is the transboundary character of an externality. If governments were able to externalize damage to the territory of another state an optimal internalization of that damage would not occur. This argument can certainly play a role with respect to many environmental problems. These are undoubtedly often transboundary. ${ }^{118}$ It is, however, difficult to apply this argument to the case of environmental liability. Many pollution cases giving rise to liability are confined within the borders of one country. Moreover, even if there is transboundary pollution, other remedies could be applied (for example international private law) that do not go as far as total harmonization. It is particularly difficult to argue that, for example, liability for soil pollution could fall within this rationale since most of the soil pollution cases (with a few exceptions) are confined within national borders. Moreover, this argument would only be a reason to harmonize issues of transboundary pollution.

\subsection{Race for the Bottom}

A second economic rationale to centralize the regulation of environmental problems is the risk of destructive competition, referred to as the 'race for the bottom' between countries that could emerge to attract foreign investments

117 See for instance Van den Bergh, Faure and Lefevere 1996, Faure 2001b, pp. 263-286 and Faure and de Smedt 2001, pp. 217-237.

118 See also Oates and Schwab 1988, pp. 333-354. They argue that as long as the effects of pollution are confined within the borders of the relevant jurisdictions, local authorities will make socially optimal decisions of environmental quality. 
with low environmental standards. As a result of this, a prisoner's dilemma could arise, whereby countries would fail to enact or enforce efficient legislation. It would mean that local governments would compete with lenient environmental legislation to attract industry. ${ }^{119}$ The result would be an overall reduction of environmental quality below efficient levels. This should correspond with the traditional game-theoretical result that prisoners' dilemmas create inefficiencies. Centralization could be advanced as a remedy for these prisoners' dilemmas.

The 'race for the bottom' argument has had several supporters as well as opponents in North American scholarship. Law and economics scholars tend to stress the benefits of competition between states and point at the dangers of centralization, ${ }^{120}$ whereas some legal scholars tend to attach more belief to the 'race for the bottom' rationale for centralization in environmental matters. ${ }^{121}$ In Europe these issues are rarely discussed in the context of the "race for the bottom' but are discussed in the European Community dogma of 'levelling the playing field to avoid distortions of competition'. This somewhat confuses the debate.

Empirical evidence to uphold this 'race for the bottom' rationale is rather weak. Repetto argues that pollution control costs are only a minor fraction of the total sales of manufacturing industries. ${ }^{122}$ Moreover, Jaffe, Portney and Stavins $^{123}$ argue that empirical evidence shows that the effects of environmental regulations are 'either small, statistically insignificant or not robust to tests of model specification'. They argue that the stringency of environmental regulations might have some effect on new firms in their decision to locate for the first time, but that this will not induce existing firms to relocate. They equally argue that other criteria such as tax levels, public services and the unionization of labour force have a much more significant impact on the location decision than environmental regulation. This empirical evidence has been somewhat contradicted by Xing and Kolstad, ${ }^{124}$ who argue that the laxity of environmental regulations in a host country is a significant determinant of foreign direct investment by the US chemical industry. The more lax the regulations, the more likely the country is to attract foreign investment, so

119 For a discussion of this theory, see Rose-Ackerman 1992b, pp. 169-170.

120 See especially with applications to environmental law, Revesz 1992, pp. 1210-1254 and Revesz 1996, pp. 2341-2416.

121 See Esty and Geradin 1998, pp. 5-46 and see Esty and Geradin 1997, pp. 265-336 in which they provide an interesting overview of the various legal instruments to deal with harmonization and apply this in the NAFTA and in the European context. See also Trebilcock and Howse 1999, pp. 5-37.

122 Repetto 1994.

123 Jaffe, Portney and Stavins 1995, pp. 132-163.

124 Xing and Kolstad 1995. 
Xing and Kolstad argue. This somewhat weakens the evidence presented by Jaffe, Portney and Stavins ${ }^{125}$ as far as the location of new firms outside the US is concerned.

All these arguments apply to the area of environmental liability as well. It is doubtful that within Europe member states would be able to engage in a game in which they would strive for low level environmental liability in order to attract industry. There is no proof of such a destructive competition towards lower liability standards and this risk is, moreover, not very realistic. Indeed, as indicated, one can doubt whether environmental liability plays a significant role in attracting or repulsing business to or from a given state. Other elements may be far more important than the level of environmental liability in location decisions of businesses. Moreover, if environmental liability were to have any effect as far as the race for the bottom is concerned, it is even more likely that states would wish to protect victims of environmental pollution instead of corporate interests. Indeed, a lenient environmental liability legislation may well run counter to the states' interests since it would limit the possibilities, for example to recover soil clean-up costs from liable polluters. If there is any effect at all one can therefore expect a 'race for the top' rather than a 'race for the bottom' in the area of environmental liability. This would enable states to recover for example costs for clean-up of (domestically) polluted soils, also from foreign polluters.

\subsection{Harmonization of Conditions of Competition}

There is a third, although not strict economic, argument advanced in the European harmonization debate, being that the harmonization of conditions of competition would be necessary to create an integrated European market. Thus differences in legal rules would endanger the creation of the integrated market.

This argument seems particularly weak. From an economic point of view, the mere fact that conditions of competition differ does not necessarily create a 'race for the bottom' risk. There can be differences in marketing conditions for a variety of reasons, and if the conditions of competition were indeed totally equal, as the argument assumes, there would also be no trade according to the theory of specialization.

Also, Europe has developed an elaborate set of rules, which guarantee, inter alia, a free flow of products and services ${ }^{126}$ and thus contribute to market inte-

125 Jaffe, Portney and Stavins 1995, pp. 132-163.

126 See Articles 28-30 of the Treaty of the European Union (the 'old' Articles 30-36). 
gration without the necessity to harmonize all rules and standards. ${ }^{127}$ In this respect one can think of the case law of the European Court of Justice with respect to the free movement of goods versus environmental protection. ${ }^{128}$ This shows that the goal of market integration can be achieved via (other) less far-reaching instruments than total harmonization ${ }^{129}$ which can equally remove barriers to trade.

The same applies for the area of environmental liability. It is very possible to create a common market without a total harmonization of all legal rules. The goal of market integration should not necessarily be achieved via this farreaching instrument of total harmonization. This would only justify for example general safety standards that aim at avoiding pointless incompatibilities which could create barriers to trade and distortions of competition within the internal market. That argument can, however, not justify a harmonization of rules of private law such as environmental liability. Finally, attempts which have been undertaken so far to harmonize rules of private law, for example in the area of product liability, have not been proved to be able to achieve a total harmonization of marketing conditions. ${ }^{130}$

\subsection{Reduction of Administrative Costs}

There is a third economic argument in favour of harmonization, which would be based on a reduction of administrative costs. This argument is often advanced by European legal scholars pleading for harmonization of private law in Europe, and is based on the argument that differences in legal systems are very complex and only serve Brussels law firms. ${ }^{131}$ This argument cannot be examined in detail here. ${ }^{132}$ It is obviously too simple to state that a harmonized legal system is always more efficient than differentiated legal rules because of the transaction costs savings inherent in harmonized rules. ${ }^{133}$ This

127 See generally on the potential conflict between free trade and environmental protection, Esty 1999, pp. 190-209.

128 For an overview of this case law, see Lefevere and Faure 1995, pp. 93-107 and Trebilcock and Howse 1999, pp. 21-28.

129 See also Esty and Geradin 1998, pp. 5-46 and see Esty and Geradin 1997, pp. 265-336 in which they provide an interesting overview of the various legal instruments to deal with harmonization and apply this in the NAFTA and in the European context (see specifically pp. 296-299); and Ogus 1994, pp. 177-179.

130 See Faure 2001b, pp. 263-286 and see Faure 2000, pp. 467-508.

131 This is one of the arguments made by the Danish scholar, Lando in favour of harmonized private law; see Lando 1993, pp. 473-474.

132 It is further developed and criticized in a paper by R. Van den Bergh; see Van den Bergh 1998, pp. 129-152.

133 For a discussion of this theory, see Rose-Ackerman 1992b, p. 172 who argues 
argument neglects the fact that there are substantial benefits from differentiation whereby legislation can be adapted to the preferences of individuals. ${ }^{134}$ Moreover, given the differences between the legal systems (and legal cultures) in Europe, the costs of harmonization may be huge - if not prohibitive - as well. ${ }^{135}$ The crucial question therefore is whether the possible transaction costs savings of harmonization outweigh the benefits of differentiated legal rules. There is little empirical evidence to support the statement that transaction costs savings could justify a European harmonization of all kinds of legal rules. Moreover, the transaction costs savings are likely to be relatively small. ${ }^{136}$

It is very doubtful whether the transaction costs argument could play a role in justifying a harmonization of environmental liability. That would only be the case if the regime were to be exclusive in the sense that it replaces national law and thus reduces existing differences. Directive 2004/35/CE, however, makes it clear that it leaves national law unaffected. ${ }^{137}$

The transaction costs argument could, however, play a role to justify the socalled negative harmonization, which aims at a co-ordination of for example product standards to prevent states from hindering a free flow of products and services. ${ }^{138}$ This type of co-operation between states can reduce transaction costs, but does not necessitate a homogenization of process standards, which is often the goal in environmental law.

The conclusion therefore is that the economic arguments to harmonize environmental rules with respect to problems which are not transboundary are relatively weak. Nevertheless, many European directives deal with problems (for example drinking water or bathing water) which are not typically transboundary and for which the European competence is therefore difficult to fit into the economic framework.

that uniform federal regulation may reduce search costs and tends to produce a more stable and predictable jurisprudence.

134 Mendelsohn 1986, p. 301.

135 That point has especially been made by Legrand (Legrand 1997, p. 111).

136 See Van den Bergh 1998, pp. 146-148.

137 See Article 16 of the directive which provides: 'This directive shall not prevent Member States from maintaining or adopting more stringent provisions in relation to the prevention and remedying of environmental damage, including the identification of additional activities to be subject to the prevention and remediation requirements of this directive and the identification of the additional responsible parties.'

138 The free flow of services was the result of directives issued as a consequence of the so-called 'Single Market Initiative'. See Vogel 1995. See on the need to harmonize product safety, M. Faure 2000. 


\section{CONCLUDING REMARKS}

The final question that of course has to be addressed within the framework of this ambitious project is what the particular regulatory function of environmental liability can be in the context of European private law on the basis of the analysis we have provided. Of course we should repeat that it is only possible to provide a partial and very cautious attempt to answer this question, given the fact that we merely addressed the regulatory function of environmental liability from a law and economic perspective and by drawing on the basis of some experiences in member states and in Europe. Notwithstanding these limits, a few conclusions can be formulated concerning the role of environmental liability in remedying environmental damage. To some extent one can hold that tort law is probably more a minor, luxury phenomenon than an instrument that would be capable of providing compensation to accident victims at any price. Indeed, Hartlief held in his inauguration address that the thresholds for tort liability are so high that it should be considered as a luxury system (in the sense that it is also the only system that guarantees full compensation). ${ }^{139}$ Even though the regulatory function of tort law in this domain of environmental harm may thus be limited (both as far as prevention and compensation is concerned), one can still argue that environmental liability (and thus private law) does have an added value.

Addressing the issue of prevention it is not difficult to argue that the primary regulatory instrument to reach prevention of environmental harm is undoubtedly public law or regulations. Shavell's public interest theory of regulation seems to obtain large support from legal practice in many European countries and at the EU level: most of the preventive measures that are required from potential polluters to reduce environmental risks are determined by regulations such as emission limit values which can be found in environmental permits. However, we argued that even as far as prevention is concerned private law and more particularly environmental liability undoubtedly plays a complementary role. This role is more particularly that environmental liability can still provide additional incentives for prevention in cases where the deterrent effect of regulation fails. Even though the intensity of regulation in the area of environmental protection is undoubtedly very intense, there are still always potential situations where the regulatory authority has (perhaps as a result of capture by private interest) defined inefficiently lenient environmental standards or has simply failed to issue norms with respect to a particular situation (for instance because that type of harm could not be foreseen when an environmental permit was granted). Particularly for these types

\footnotetext{
139 Hartlief 1979.
} 
of situations the knowledge that even though public regulations have been followed (which has to be seen as a minimum) the injurer can still be held liable, will undoubtedly offer a complementary deterrent effect. Moreover, where lawyers are traditionally rather suspicious and even critical of a potential role of tort law in preventing damage, they seem to attach much more belief to the preventive function of liability rules in the area of environmental harm, probably because these rules are largely addressed to professional risk creators. Hence there is at least a (limited but not unimportant) added value of environmental liability in providing complementary incentives for prevention in cases where regulation fails.

Also as far as compensation is concerned environmental liability can have an added value for the simple reason that it is the only regime that guarantees complete indemnification of the victim. The major weakness of environmental liability is that a liability without solvency guarantees does not offer any security that compensation will effectively take place. Therefore this added value of tort law (complete indemnification) has to be combined with other mechanisms in order to guarantee that environmental liability can also exercise this regulatory function of providing compensation to victims of environmental harm. Liability insurance could be such a mechanism, although the application of the classic liability insurance to environmental harm leads to several problems, as has been held by many in the literature. Environmental risks are still relatively new; therefore reliable statistics on accident frequency and potential scope of the damage are still lacking. Moreover, environmental damage is such a vague notion that the predictability is often difficult. To this can be added that the conditions for environmental liability in (national) case law are still in full evolution. That makes it rather difficult for a liability insurer to estimate what the probability may be that his insured injurer would be held liable to a third party for environmental damage. To this can be added the risk that new liability rules would be applied with retrospective effect in all situations and that the risk of causal uncertainty would be shifted to the risk creator, or that he could be held jointly and separately liable also for damage that is (at least partially) caused by others. All of these elements make it easy to understand that insurers consider environmental liability a difficult to insure risk. Some of the evolutions we outlined are considered by some insurers as so serious that they consider the environmental liability risk as uninsurable. In some countries insurers have already been withdrawing from the liability insurance market. This withdrawal of insurers from the environmental liability market can seriously endanger the functioning of environmental liability in providing compensation for environmental harm. Without a solvency guarantee it may be clear that environmental liability also cannot exercise its regulatory function in compensating environmental harm.

Therefore in some countries, for example the Netherlands amongst others, 
insurers have moved to another system of coverage. This is no longer based on environmental liability, but on a direct insurance of the particular site. It is held that direct insurance would be better able than liability insurance to provide an effective differentiation of risks. But notwithstanding the advantages we also indicated that questions still arise concerning this direct insurance. One of the problems is that of course (as is always the case with first-party insurances) the conditions of coverage will be determined in the insurance policy. These conditions will, understandably, try to limit the risk for the insurer in order to keep the risk insurable. Another problem is that the entire Dutch insurance market switched to direct insurance. As a result of this it is no longer possible to get insurance mainly on the basis of environmental liability. This shows that serious questions can be asked as far as the competitiveness of insurance markets is concerned. Environmental liability can only exercise its regulatory function in compensating harm when a wide variety of differentiated policies are offered in a competitive insurance and financial market among which potentially responsible partners can choose. One cannot escape the impression that in some cases a too strong co-operation between insurers limits the offer of insurance policies, precisely as competition theory would predict.

The importance of the availability of insurance or alternative methods of coverage is, as we have shown, not only important to guarantee compensation to the victim. In the case of insolvency there is also the risk that environmental liability cannot exercise its regulatory function of prevention since insolvency may lead to underdeterrence. Hence, the law and economic literature strongly supports pleas in favour of a duty for potential responsible parties to seek financial coverage to meet their obligations. A problem, however, is that it is doubtful whether today's European insurance markets are sufficiently developed to be able to execute an outright duty to insure. Thus it seems more pragmatic to provide competent authorities with the possibility to demand financial guarantees from potentially responsible parties, for example in environmental permits. This individualized approach has the advantage that the competent authority can take into account the individual situation of the particular potential polluter.

\section{REFERENCES}

Abraham, K. (1988), 'Environmental Liability and the Limits of Insurance', 88 Columbia Law Review, 957-959.

Adams, M. (1989), 'New Activities and the Efficient Liability Rules', in M. Faure and R. Van den Bergh (eds.), Essays in Law and Economics. Corporations, Accident Prevention and Compensation for Losses.

Akkermans, A. (1997), Proportionele aansprakelijkheid bij onzeker causaal verband. Arcuri, A. (2001), 'Controlling Environmental Risk in Europe: The Complementary 
Role of an EC Environmental Liability Regime', Tijdschrift voor Milieuaansprakelijkheid (TMA), 39-40.

Bergkamp, L. (2000a), 'The Proper Scope of Joint and Several Liability', TMA, 154-155.

Bergkamp, L. (2000b), 'The Commission's White Paper on Environmental Liability: A Weak Case for an EC Strict Liability Regime', EELR, 112-114.

Bergkamp, L. (2001), Liability and Environment, The Hague/London, Kluwer Law International 208.

Bocken, H. (1987), 'Alternatives to Liability and Liability Insurance for the Compensation of Pollution Damages', TMA, 83-87 and (1988) TMA, 3-10.

Bocken, H. (1992), 'La réparation des Dommages causées par la Pollution au Droit Belge. La Situation en 1992', Tijdschrift voor Belgisch Burgerlijk Recht, 284-327.

Bocken, H. (1993), L'Assurance Responsabilité Civile pour Dommages causées par la Pollution, in Les Assurances de l'Entreprise, Actes du Collogues tenu à l'Université Libres des Bruxelles les 2 et 3 décembre 1993.

Bocken, H., W. Lambrecht, M. Boes, A. De Nauw, M. Faure, L. Lavrysen (1996), 'The Flemish Draft Decree on Environmental Policy: An Outline', in H. Bocken, D. Ryckbost (eds.), Codification of Environmental Law. Proceedings of the International Conference, pp. 31-32.

Bocken, H. and D. Ryckbost (1991) (eds.), Verzekering van Milieuschade, Insurance of Environmental Damage.

Brans, E.H.P. (1994), 'Liability for Ecological Damage under the 1992 Protocols to the Civil Liability Convention and the Fund Convention and the Oil Pollution Act of 1990', TMA, 61-67 and 85-91.

Brown, J.P. (1973), 'Toward an Economic Theory of Liability', Journal of Legal Studies (JLS), 343.

Brüggemeier, G. (1991), 'Liability for Water Pollution under German Law: Fault or Strict Liability', in J. van Dunné (ed.), Transboundary Pollution and Liability: The Case of the River Rhine, pp. 88-91.

Burrows, P. (1999), 'Combining Regulation and Liability for the Control of External Costs', 19 IRLE, 227-242.

Calabresi, G. (1961), 'Some Thoughts on Risk Distribution and the Law of Torts', Yale Law Journal, 499-553.

Calabresi, G. (1970), The Costs of Accidents, A Legal and Economic Analysis.

Calabresi, G. (1975), 'Optimal Deterrence and Accidents', 84 YLJ, 658.

Coghlin, T.G. (1984), 'Protection and Indemnity Clubs', Lloyd's Maritime and Commercial Law Quarterly, 403-416.

Cooter, R. (1984), 'Prices and Sanctions', 84 Columbia Law Review, 1343-1523.

Cooter, R. and Th. Ulen (2000), Law and Economics, 3rd edition, pp. 316-318.

Cortenraad, W.H.F.M. (2000), The Corporate Paradox. Economic Realities of the Corporate Form of Organization.

Cousy, H. (1995), 'Recent Developments in Environmental Insurance', in F. Abraham, K. Deketelaere and J. Stuyck (eds.), Recent Economic and Legal Developments in European Environmental Policy, pp. 227-241.

Deprimoz, J. (1995), 'Régime Juridique des Assurances contre les Risques Nucléaires', Juris. Classeur, 1-24.

De Putter, P. and J. Verschuuren (1995), 'Een milieuschadefonds in Nederland?', MenR, 96-99.

Dewees, D. (1992a), 'The Comparative Efficacy of Tort Law and Regulation for Environmental Protection', GPRI, 446-467. 
Dewees, D. (1992b), 'Tort Law and the Deterrence of Environmental Pollution', in T.H. Tietenberg (ed.), Innovation in Environmental Policy, Economic and Legal Aspects of Recent Developments in Environmental Enforcement of Liability, pp. 139-164.

Dewees, D., D. Duff and M. Trebilcock (1996), Exploring the Domain of Accident Law; Taking the Facts Seriously.

Diamond, P. (1974), 'Single Activity Accidents', JLS, 107-164.

Drion, P.J.M. (1998), 'Milieu onder één dak: milieuschadeverzekering' (MSV), Verzekeringsrechtelijke Berichten, 19-21.

Endres, A. and R. Schwarze (1991), 'Allokationswirkungen einer Umwelthaftpflichtversicherung', Zeitschrift für Umweltpolitik und Umweltrecht (ZUU), 1-25.

Endres, A. and B. Staiger (1996), 'Ökonomische Aspekte des Umwelthaftungsrecht', in M. Ahrens and J. Simon (eds.), Umwelthaftung, Risikosteuerung und Versicherung, pp. 79-93.

Estep, E. (1960), 'Radiation Injuries and Statistics: The Need for a New Approach to Injury Litigation', Michigan Law Review (MLR), 259-304.

Esty, D. (1999), 'Economic Integration and the Environment', in N. Vig and R. Axelrod (eds.), The Global Environment, pp. 190-209.

Esty, D. and D. Geradin (1997), 'Market Access, Competitiveness and Harmonization: Environmental Protection in Regional Trade Agreements', 21 Harvard Environmental Law Review (HELR), 265-336.

Esty, D. and D. Geradin (1998), 'Environmental Protection and International Competitiveness. A Conceptual Framework', 32/3 Journal of World Trade (JWT), 5-46.

Faure, M. (1995a), 'Economic Models of Compensation for Damage Caused by Nuclear Accidents: Some Lessons for the Revision of the Paris and Vienna Conventions', European Journal of Law and Economics (EJLE), 21-43.

Faure, M. (1995b), 'The Limits to Insurability from a Law and Economics Perspective', Geneva Papers on Risk and Insurance (GPRI), 454-462.

Faure, M. (2000), 'Product Liability and Product Safety in Europe: Harmonization or Differentiation?', 53 Kyklos, 467-508.

Faure, M. (2001a), 'Tort Liability in France: An Introductory Economic Analysis', in B. Deffains and Th. Kirat (eds.), Law and Economics in Civil Law Countries, pp. $169-181$.

Faure, M. (2001b), 'Regulatory Competition versus Harmonization in EU Environmental Law', in D. Esty and G. Geradin (eds.), Regulatory Competition and Economic Integration, pp. 263-286.

Faure, M. (ed.) (2003), Deterrence, Insurability, and Compensation in Environmental Liability. Future Developments in the European Union.

Faure, M. (2004), 'Alternative Compensation Mechanisms as Remedy for Uninsurability of Liability', The Geneva Papers on Risk and Insurance, vol. 29, no. 3, 455-489.

Faure, M. (2007), 'Shift Toward Alternative Compensation Mechanisms for Environmental Damage?', in M. Faure and A. Verhey (eds.), Shifts in Compensation for Environmental Damage, Vienna, Springer, pp. 73-102.

Faure, M. and P. Fenn (1999), 'Retroactive Liability and the Insurability of Long-tail Risks', IRLE, 487-500.

Faure, M. and D. Grimeaud (2003), 'Financial Assurance Issues of Environmental Liability', in M. Faure (ed.), Deterrence, Insurability and Compensation in Environmental Liability. Future Developments in the European Union, Vienna, Springer, 68-122. 
Faure, M. and T. Hartlief (1996a), Ontwikkelingen in de werkgeversaansprakelijkheid voor beroepsziekten: aanleiding voor een nieuwe AVB-polis?, A\&V, 140-150.

Faure, M. and T. Hartlief (1996b), 'Towards an Expanding Enterprise Liability in Europe? How to Analyse the Scope of Liability of Industrial Operators and their Insurers', Maastricht Journal of European and Comparative Law (MJ), 254-259.

Faure, M. and T. Hartlief (1996c), 'Compensation Funds versus Liability and Insurance for Remedying Environmental Damage', Review of European Community and International Environmental Law, 321-326.

Faure, M. and T. Hartlief (2003), 'Insurance and Expanding Systemic Risks', Paris, $O E C D$, p. 260.

Faure, M. and G. Heine (1991), 'The Insurance of Fines: The Case of Oil Pollution', GPRI, 39-54.

Faure, M. and M. Ruegg (1994), 'Standard Setting through General Principles of Environmental Law', in M. Faure, J. Vervaele and A. Weale (eds.), Environmental Standards in the European Union in an Interdisciplinary Framework, pp. 39-60.

Faure, M. and G. Skogh (1992), 'Compensation for Damages Caused by Nuclear Accidents: A Convention as Insurance', GPRI, 499-513.

Faure, M. and K. de Smedt (2001), 'Should Europe Harmonize Environmental Liability Legislation?', Environmental Liability, vol. 5, 217-237.

Faure, M. and R. Van den Bergh (1995), 'Restrictions of Competition on Insurance Markets and the Applicability of EC Anti-Trust Law', Kyklos, 65-85.

Gardner, M. (1990), 'Results of a Case-control Study of Leukaemia and Lymphoma Among Young People Near Sellafield Nuclear Plant in West Cumbria', British Medical Journal, 423-434.

Gilhuis, P. and J. Verschuuren (1994), 'Een milieuschadefonds in Nederland; een onderzoek naar de mogelijkheden', Publicatiereeks Milieubeheer, 3.

Gimpel-Hinteregger, M. (1994), Grundfragen des Umwelthaftung.

Hager, G. (1993), 'Umwelthaftungsgesetz: The New German Environmental Liability Law', EL, pp. 41-44.

Hansmann, H. and R.H. Kraakman (1991), 'Toward Unlimited Shareholder Liability for Corporate Torts', 100 YLJ, 1879.

Hartkamp, G. (1992), Tijdschrift voor Consumentenrecht (TvC), 241-258.

Hartlief, T. (1997), Ieder draagt zijn eigen schade, inauguration address, Deventer, Kluwer.

Hulst, E. (1993), Grondslagen van Milieuaansprakelijkheid.

Hulst, E. (1995), 'De werkelijkheid rondom een algemeen milieuschadefonds, een commentaar', TMA, 167-173.

Interuniversitaire Commissie voor de Herziening van het Milieurecht in het Vlaamse Gewest (1995), Voorontwerp Decreet Milieubeleid, pp. 943-985.

Jaffe, A., S. Portney and R. Stavins (1995), 'Environmental Regulation and the Competitiveness of US Manufacturing: What Does the Evidence Tell Us?', Journal of Economic Literature (JEL), 33, 132-163.

Janssen, C.A. (1998), 'Aansprakelijkheid voor milieuschade en financiële zekerheid naar toekomstig recht: nieuwe oplossingen. Nederlands Recht', in L.F. WiggersRust and K. Deketelaere (eds.), Aansprakelijkheid voor milieuschade en financiële zekerheid, pp. 111-112.

Jones, B. (1997), 'Deterring, Compensating and Remedying Environmental Damage: the Contribution of Tort Liability', in P. Wetterstein (ed.), Harm to the Environment: The Right to Compensation and the Assessment of Damages, pp. 11-27.

Jones, B. (1999), 'Environmental Law in the United Kingdom', in N.S.J. Koeman, (ed.), Environmental Law in Europe. 
Jost, P.J. (1996), 'Limited Liability and the Requirement to Purchase Insurance', IRLE, 259-276.

Katzman, M. (1988), 'Pollution Liability Insurance and Catastrophic Environmental Risk', Journal of Risk and Insurance (JRI), 89-90.

Kerremans, H. (1999), 'Aansprakelijkheid voor milieuschade en verzekeringsmogelijkheden', in Milieuzorg in de onderneming I, Juridische, Fiscale en Organisatorische Aspecten, pp. 537-583.

Knottenbelt, J. (1990), Produktaansprakelijkheid.

Kolstad, Ch.D., Th.S. Ulen and G.V. Johnson (1990), 'Ex Post Liability for Harm vs. Ex Ante Safety Regulation: Substitutes or Complements?', 80 American Economic Review (AER), 888-901.

Kottenhagen-Edzes, P.A. (1992), Onrechtmatige daad en milieu. Het gebruik van het privaatrecht bij het voorkomen van milieu-aantasting en het verhaal van milieuschade.

Koziol, H. (1997), Österreichisches Haftpflichtrecht.

Kunreuther, H. and P. Freeman (2001), 'Insurability, Environmental Risks and the Law, in A. Heyes (ed.), The Law and Economics of the Environment, pp. 304-316.

Kunreuther, H., R. Hogarth and J. Meszaros (1993), 'Insurer Ambiguity and Market Failure', Journal of Risk and Uncertainty, 71-87.

Landes, W. and R. Posner (1981), 'The Positive Economic Theory of Tort Law', Georgia Law Review (GLR), 870.

Landes, W. and R. Posner (1984), 'Tort Law as a Regulatory Regime for Catastrophic Personal Injuries', $J L S, 417$.

Lando, O. (1993), 'Die Regeln des Europäischen Vertragsrecht', in P. Müller-Graff (ed.), Gemeinsames Privatrecht in der Europäischen Gemeinschaft, pp. 473-474.

Lang, R. (1996), Die neue Umwelt-Haftpflichtversicherung nach dem HUK-Modell', in M. Ahrens and J. Simon (eds), Umwelthaftung, Risikosteuerung und Versicherung, pp. 169-183.

Lavrysen, L. (1995), 'Judicial Responses in the Nineties to Dutch (and German) Shipments of Waste to Belgium in the Eighties', MJ, 219-243.

Lefevere, J. and M. Faure (1995), 'Introduction to European Environmental Law', in T. Kegels (ed.), Shipping Law faces Europe: European Policy Competition and Environment, pp. 93-107.

Legrand, B (1997), 'The Impossibility of "Legal Transplants" , MJECL, 111.

Mackaay, E. (1982), Economics of Information and the Law.

McIntyre, O. (1996), 'The UK Environmental Act 1995: Section 57: A Contaminated Land Regime at Last!', 4 EL 4, 67-74.

Mendelsohn, R. (1986), 'Regulatory Heterogeneous Emissions', 13 Journal of Environmental Economics and Management (JEEM), 301.

Monti, A. (2001), 'Environmental Risk: A Comparative Law and Economics Approach to Liability and Insurance', European Review of Private Law (ERPL), 51-79.

Niezen, J. (1998), 'Nieuwe milieuschadeverzekering - geen panacee', MenR, 114.

Niezen, G.J., M.J.G.C. Raaijmakers and A.J.S.M. Tervoort (2000) (eds.), 'Aansprakelijkheid voor milieuschade in de Europese Unie' in Ongebonden Recht Bedrijven, p. 171.

Oates, W.A. and R.M. Schwab (1988), 'Economic Competition Among Jurisdictions: Efficiency Enhancing or Distortion Inducing?', 35 Journal of Public Economics, 333-354.

Ogus, A. (1994), Regulation, Legal Form and Economic Theory.

Pape, K.A. and K. Schillhorn (1999), 'Environmental Law in the Federal Republic of Germany', in N.S.J. Koeman (ed.), Environmental Law in Europe. 
Polborn, M. (1998), 'Mandatory Insurance and the Judgement-Proof Problem', IRLE, 141-146.

Polinsky, A.M. (1983), Introduction to Law and Economics.

Priest, G. (1987), 'The Current Insurance Crisis and Modern Tort Law', YLJ, 1521-1590.

Ranson, D. (2000), 'Verzekering van milieuaansprakelijkheid', $M \& R, 68$.

Repetto, R. (1994), Trade and Sustainable Development, UNEP, Environment and Trade Series.

Revesz, R. (1992), 'Rehabilitating Interstate Competition: Rethinking the "Race for the Bottom” Rationale for Federal Environmental Regulation', 67 New York University Law Review (NYULR), 1210-1254.

Revesz, R. (1996), 'Federalism and Interstate Environmental Externalities', 144 University of Pennsylvania Law Review (UPLR), 2341-2416.

Revesz, R.L. and R.W. Stewart (1995), Analysing Superfund, Economics, Science and Law.

Richardson, B.J. (2000), 'Financial Institutions for Sustainability', EL, 52-64.

Robinson, G. (1985), 'Probabilistic Causation and Compensation for Tortious Risk', $J L S, 798$.

Rogge, J. (1997), Les assurances en matière d'environnement.

Rose-Ackerman, S. (1992a), 'Environmental Liability Law', in T.H. Tietenberg (ed.), Innovation in Environmental Policy, Economic and Legal Aspects of Recent Developments in Environmental Enforcement and Liability, pp. 223-243.

Rose-Ackerman, S. (1992b), Rethinking the Progressive Agenda. The Reform of the American Regulatory State.

Rose-Ackerman, S. (1995a), Controlling Environmental Policy: the Limits of Public

Law in Germany and the United States.

Rose-Ackerman, S. (1995b), 'Public Law versus Private Law in Environmental Regulation: European Union Proposals in the Light of United States Experience', 4 Review of European Community and International Environmental Law (RECIEL), 312-332.

Rose-Ackerman, S. (1996), 'Public Law versus Private Law in Environmental Regulation: European Union Proposals in the Light of United States and German Experiences', in E. Eide and R. van den Bergh (eds.), Law and Economics of the Environment, pp. 13-39.

Rosenberg, D. (1984), 'The Causal Connection in Mass Exposure Cases: A "Public Law" Vision of the Tort System', HLR, 851-929.

Schmitz, P.W. (2000), 'On the Joint Use of Liability and Safety Regulation', 20 IRLE, $371-382$.

Schwartz, A. and L. Wilde (1979), 'Intervening in Markets on the Basis of Imperfect Information: A Legal and Economic Analysis', University of Pennsylvania Law Review (UPLR), 630-682.

Schwartz, G. (1997), 'Mixed Theories of Tort Law: Affirming both Deterrence and Corrective Justice', 75 Texas Law Review (TLR), 1801-1834.

Shavell, S. (1980), 'Strict Liability versus Negligence', JLS, 1-25.

Shavell, S. (1984a), 'Liability for Harm versus Regulation of Safety', JLS, 357-374.

Shavell, S. (1984b), 'A Model of the Optimal Use of Liability and Safety Regulation', Rand Journal of Economics (RJE), 271-280.

Shavell, S. (1985a), 'Criminal Law and the Optimal Use of Non-monetary Sanctions as a Deterrent', Columbia Law Review, 1232-1262.

Shavell, S. (1985b), 'Uncertainty over Causation and the Determination of Civil Liability', JLE, 587-609. 
Shavell, S. (1986), 'The Judgement Proof Problem', IRLE, 43-58.

Shavell, S. (1987), Economic Analysis of Accident Law.

Skogh, G. (2000), 'Mandatory Insurance: Transaction Costs Analysis of Insurance', in B. Bouckaert and G. de Geest (eds.), Encyclopedia of Law and Economics, pp. 521-537.

Smets, H. (1997), 'COSCA: A Complementary System for Compensation of Accidental Pollution Damage', in P. Wettenstein (ed.), Harm to the Environment: The Right to Compensation and the Assessment of Damage, pp. 223-248.

Spier, J. (1990), Sluipende schade.

Stigler, G. (1961), 'The Economics of Information', Journal of Political Economics (JPE), 213.

Trauberman, J. (1983), 'Statutory Reform of "Toxic Torts". Relieving Legal, Scientific and Economic Burdens on the Chemical Victim', Harvard Environmental Law Review (HELR), 177-296.

Trebilcock, M. and R. Howse (1999), 'Trade Liberalization and Regulatory Diversity, Reconciling Competitive Markets with Competitive Politics', 6 European Journal of Law and Economics (EJLE), 5-37.

Van, A. (1994), 'Statistisch bewijs van causaal verband, Discussion of High Court of Justice 8 October 1993 (Sellafield Claims)', TMA, 109-118.

Van, A. (1995), Onzekerheid over daderschap en causaliteit.

Van den Bergh, R. (1998), 'Subsidiarity as an Economic Demarcation Principle and the Emergence of European Private Law', Maastricht Journal of European and Comparative Law (MJECL), 129-152.

Van den Bergh, R., M. Faure and J. Lefevere (1996), 'The Subsidiarity Principal in European Environmental Law: An Economic Analysis', in E. Eide and R. Van den Bergh (eds.), Law and Economics of the Environment.

Vanden Borre, T. (2001), Efficiënte preventie en compensatie van catastroferisico's. Het voorbeeld van schade door kernongevallen.

Veljanovski, C.G. (1981), 'The Economic Theory of Tort Liability - Toward a Corrective Justice Approach', in P. Burrows and C.G. Veljanovski (eds.), The Economic Approach to Law, pp. 125-150.

Viscusi, W.K. (1991), The Dimensions of the Product Liability Crisis, JLS, 147-177.

Vogel, D. (1995), Trading Up: Consumer and Environmental Regulation in the Global Economy.

Wagner, G. (1999), 'Haftung und Versicherung als Instrumente der Techniksteuerung', Versicherungsrecht (VR), 1441-1480.

Wansink, J.H. (1985), 'De nieuwe milieuaansprakelijkheidsverzekering', $M \& R, 98$.

Wansink, J.H. (1997), 'Hoe plotseling en onzeker is de verzekeringsdekking voor millieuaansprakelijkheidsrisico's?', in J. ten Kate et al (eds.), Miscellanea. Jurisconsulto vero dedicata, Essays offered to Prof. Mr. J.M. van Dunné, pp. 451-460.

Wansink, J.H. (1999), 'Verzekering en milieuschade als gevolg van vervoer/opslag van gevaarlijke stoffen ', TMA, 77-82.

Wittman, D. (1980), 'First Come, First Served: An Economic Analysis of "Coming to Nuisance", , JLS, 557-568.

Xing, Y. and C. Kolstad (2002), 'Do Lax Environmental Regulations Attack Foreign Investment?', Environmental and Resource Economics, 21, 1-22.

Zeckhauser, R. (1996), '19th Annual Lecture of the Geneva Association and Catastrophes', GPRI, 5. 